\title{
How to Prevent Flow Failures in Tailings Dams
}

\author{
Roberto Rodríguez ${ }^{1}$ (]) Alejandro Muñoz-Moreno ${ }^{1,2} \cdot$ Ana Vanessa Caparrós $^{3}$. Cristóbal García-García ${ }^{4}$. \\ Ángel Brime-Barrios ${ }^{5}$. Julio César Arranz-González ${ }^{1}$. Virginia Rodríguez-Gómez ${ }^{1}$. \\ Francisco Javier Fernández-Naranjo ${ }^{1}$ - Alberto Alcolea ${ }^{3}$
}

Received: 10 June 2020 / Accepted: 14 January 2021 / Published online: 17 February 2021

(c) The Author(s) 2021

\begin{abstract}
Based on research carried out at 67 tailings dams in Spain: (1) tailings dams contain alternating sedimentary layers with contractive and dilative geomechanical behaviours; (2) tailings saturate quickly but drain more than 10 times slower due to the high-suction capacity of the porous sediments (2-300 MPa); and (3) over the long-term, a stationary flow regime is attained within a tailings basin. Four temporal and spatial conditions must all be present for a tailing dams flow failure to occur: (1) the tailings must experience contractive behaviour; (2) the tailings must be fully saturated; (3) the effective stress due to static or dynamic load must approach zero; and (4) the shear stress must exceed the tailings residual shear stress. Our results also indicate that the degree of saturation $\left(\mathrm{S}_{\mathrm{r}}\right)$ is the most influential factor controlling dam stability. The pore-pressure coefficient controls geotechnical stability: when it exceeds $0.5\left(S_{r}=0.7\right)$, the safety factor decreases dramatically. Therefore, controlling the degree of tailings saturation is instrumental to preventing dam failures, and can be achieved using a double drainage system, one for the unconsolidated foundation materials and another for the overlying tailings.
\end{abstract}

Keywords Liquefaction $\cdot$ Storage-cover release $\cdot$ Double drainage system $\cdot$ Tailings management facilities

\section{Introduction}

Tailings dams (TDs) failures have been widely addressed (e.g. Agurto-Detzel et al. 2016; ICOLD 2001; AyalaCarcedo 2004; Oldecop et al. 2008; Zandarín et al. 2009; WMTF 2020), along with their environmental consequences (Caruccio and Geidel 1984; Dold 2014; Dold and Fontboté 2002; Gammons et al. 2000; García 2004;

Roberto Rodríguez

roberto.rodriguez@igme.es

1 Instituto Geológico y Minero de España, Ríos Rosas, 23, 28003 Madrid, Spain

2 Departamento de Estratigrafía, Facultad de Ciencias Geológicas, Universidad Complutense de Madrid, Calle José Antonio Novais, 12, 28040 Madrid, Spain

3 SAIT, Edificio I+D +i, Universidad Politécnica de Cartagena, 30202 Cartagena, Murcia, Spain

4 Universidad Politécnica de Cartagena, Paseo Alfonso XIII, 30202 Cartagena, Murcia, Spain

5 E.T.S.I. Minas y Energía, Universidad Politécnica de Madrid, Ríos Rosas, 21, 28003 Madrid, Spain
Roche et al. 2017), and geotechnical stability (Alonso and Gens 2006; Ishikara 1993; Ishihara et al. 1980; Newland 2014; Robertson et al. 2019; Smith 1969, 1973; Verdugo 2012; Yu et al. 2019). Many case studies show that active, restored, and abandoned tailings dams (TDs) fail, and sometimes develop a flow failure (FF). A statistical summary of the main TD failures from 1915 to January 2020 shows that static triggering mechanisms were the predominant cause (Fig. 1).

Numerous post-failure investigations have concluded that more than one defect in the design, construction, and/or operation must converge before TDs fail (Alonso and Gens 2006; ANCOLD 2019; CDA 2014; Crippen 2018; ICOLD 1982; Oldecop and Rodríguez 2006; Rico et al. 2008; Rodríguez 2018; WISE 2020; WMTF 2020). TD failure is a consequence of a flaw of design, construction, or management, or a combination of these (Brown et al. 1969; Caruccio and Geidel 1984; Jennings 1971; Martin et al. 2002; Morgenstern et al. 2016; Rodríguez 2018; Smith 1969; Van Zyl and Robertson 1980; Zandarín et al. 2009). Martin et al. (2002) provide 10 basic rules of good practice for the design, construction, and management of upstream TDs that should 
also be followed for centerline and downstream types. These 10 rules are by no means new, and are restatements of principles outlined by previous authors (Casagrande 1950, 1975; Casagrande and MacIver 1970; Ladd 1986; Lenhart 1950; Martin and McRoberts 1999; Martin et al. 2002; Robertson 2010; Robertson et al 2019; Rodríguez 2018; Smith 1969; Vick 1992). In all TD failures, more than three of these 10 basic rules have been broken (Martin et al. 2002; Oldecop and Rodríguez 2006; Robertson 2010). The profile of upstream TDs that failed in the major FF disasters (e.g. Tlalpujahua-Mexico, El Cobre and Borahona in Chile, Mochikoshi-Japan, Stava-Italy, Mount Polley-Canada, Brumadinho, Correogo do Feijão in Brasil, and others) is very different from the ideal one described by many authors (ICOLD 2001; Martin et al. 2002; Rodríguez et al. 2011; Smith 1973; Vick 1992; WMTF 2020). The TDs that fail most frequently were built using the upstream method. However, statistical data can give a misleading perspective, because more than $99 \%$ of the existing TDs in Spain are upstream (IGME 2020), and 95\% of the TDs in the world were built using a hydraulic filling system for the tailings discharge (Rodríguez 2018).

Every TD is a unique structure at a unique site and therefore requires a unique design; "off-the-shelf" designs have no place in modern tailings management facilities. Therefore, engineering experience in tailings disposal must be integrated with the results of theoretical, field, and laboratory studies to develop the most economical and safe techniques against liquefaction and FF (Robertson 2010; Morgenstern et al. 2016).

Figure 2 shows the behaviour of contractive and dilative granular materials under shear stress $(\tau)$ in undrained conditions (Fig. 2a-d). The critical state line (CSL) delimits tailings materials behaviour (Fig. 2d), which is determined by the initial state of the material in terms of its void ratio (e) and confining effective stress $\left(\mathrm{p}^{\prime}\right)$. If the material is initially above the CSL in the compression plane, then the

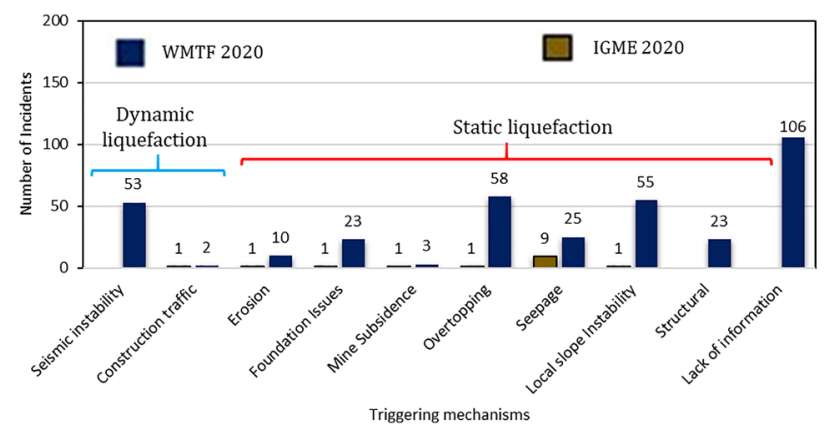

Fig. 1 a Number of incidents according to the principal triggering mechanisms of TDs failures, $\mathbf{b}$ number of incidents of TDs failures related to dam height, from 1915 to January 2020 (IGME 2020; WMTF 2020). The numbers on the left correspond to flow failure a tailings dam in Spain behaviour will be contractive. However, if materials are below the CSL, the behaviour will be dilative. The shear stress and deformation produce a tendency for the materials to contract and develop an excessive pore-pressure faster than TDs drainage systems can relieve (Hazen 1918; Moller et al. 2009; Knappett and Craig 2012; Kokusho 1991, 2003; Kokusho and Kojima 2002; Whitman 1987).

\section{Static Slope Failure, Liquefaction, and Flow Failure}

Static slope failure occurs when the imposed stress on an embankment or foundation exceeds the peak effective shear stress-shear strain (strength-deformation, Fig. 2e). As sandy and silty soils, tailings will liquefy when the effective stress $\left(\sigma^{\prime}\right)$ approaches zero; by Terzaghi's principle (Eq. 1), this occurs when pore pressure $(\mathrm{u})=$ total stress $(\sigma)$.

$\sigma^{\prime}=\sigma+\mathrm{u}$

The principle of effective stress $\left(\sigma^{\prime}\right)$ applies only to fully saturated granular soils (e.g. tailings, sand, silt), and relates the following three stresses (Knappett and Craig 2012):

- The total normal stress $\sigma$ on a plane within the soil mass is the force per unit area transmitted in a normal direction across the plane, taking the soil as a solid material.

- The pore water pressure $(\mathrm{u})$ is the pressure of the water filling the void space or void ratio between the solid particles.

- The effective normal stress $\left(\sigma^{\prime}\right)$ on the plane represents the stress transmitted only through the soil skeleton (i.e. due to interparticle forces).

Based on this principle, shear stress resistance of the tailings is defined by:

$\tau=(\sigma-\mathrm{u}) \times \operatorname{tang} \varphi+\mathrm{c}+\mathrm{s}$,

where $\tau$ is the shear stress, $\sigma$ is the normal stress on the sliding plane, $\mathrm{u}$ is the pore water pressure, $\varphi$ is the internal friction angle, $\mathrm{c}$ is the cohesion, and $\mathrm{s}$ is suction. The last two variables are the shear stress interparticle components that are characteristics of the tailings material. The internal friction angle ranges from 21 to $41^{\circ}$ for the tailings (Rodríguez 2006, 2018). The cohesion is null for sand and null or low for sand-silt-sized tailings (Garino 2018; Rodríguez 2006, 2018).

According to Eq. 2, when the pore water pressure increases, the shear stress resistance of the material decreases, until at some point, the geotechnical stability of the dam is lost. Pore pressures can rise because of excessive dam rising rate, transit of machinery, blasting, seismic events, injection of water due to failure of the drainage system, and other factors. 
The two main factors that affect the static stability of a slope are the shear strength of the TD and the pore pressure. Static liquefaction refers to the process whereby a contractive granular material (soils, tailings, gravels, loess, etc.), that is more than $80 \%$ saturated, loses its strength in response to applied static stress. A clear instability (flow or mudflow failure) appears when permanent loading exceeds the residual shear stress $\left(\mathrm{S}_{\mathrm{u}}\right)$ in undrained conditions (Fig. 2e). Static liquefaction can be caused by increased pore pressure due to an excessive dam rising rate (m/years or $\mathrm{m} /$ months) and other processes that alter the stress state of the TD, causing the load to exceed the peak of the shear stress (resistance)-shear strain (deformation) of the material. These include: (1) overtopping, (2) internal erosion, (3) erosion of the dam toe, (4) foundation collapse, (5) injection of water due to a drainage system failure, (6) an increase in the water table due to extraordinary contributions of rain or snow melt and increased metallurgical production, and (7) collapse due to increased saturation caused by the input of groundwater, etc. (Rodriguez 2018).

However, it is important to recognize that in all cases, whatever the triggering mechanism (Fig. 1), the forces that ultimately drive the liquefaction and the flow failure of liquefied material are permanent or gravitational. In this sense, the types of liquefaction "dynamic" or "static" do not differ at all and hence their effects are identical (Rodríguez 2018). Static liquefaction can result from slope instability issues alone or can be triggered by other mechanisms (Nguyen and Boger 1998; Oldecop and Rodríguez 2006; Olson and Stark 2003; Rodríguez 2018).

We investigated the key controlling factors for TDs failures to assess which were the most influential. We integrated geomorphological and geotechnical mapping and field sampling of several TDs with physic-chemical, geomechanical, and hydraulic laboratory tests, to obtain a representative a

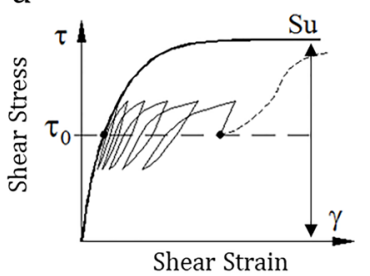

$\mathrm{e}$

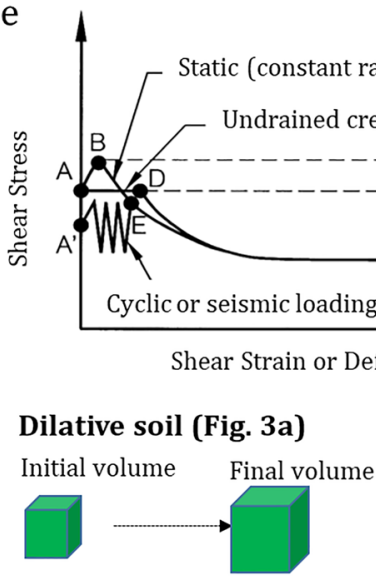

Contractive soil (Figs. 3b, C)

Initial volume Final volume

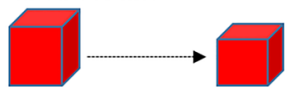

b

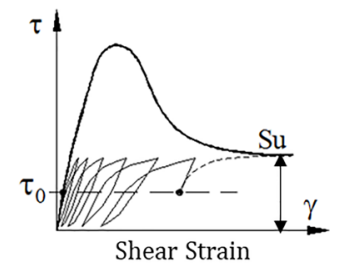

$\mathrm{C}$

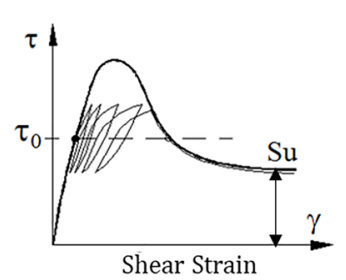

Yield Strength Envelope
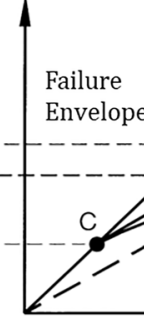

Normal or Vertical Effective Stress d

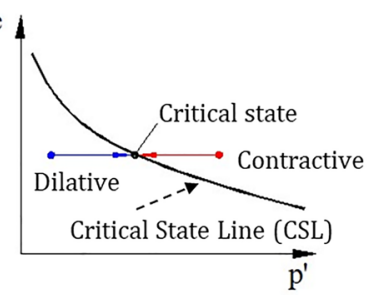

f

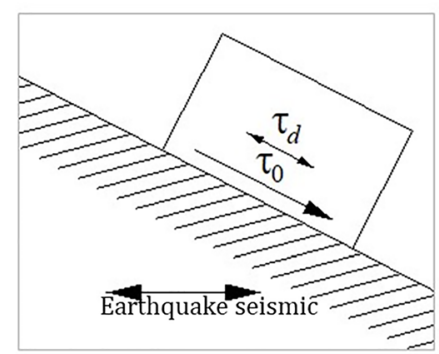

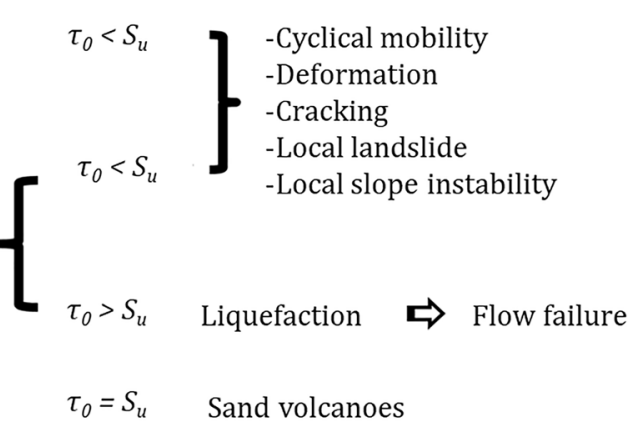

Fig. 2 Geotechnical response of sediment in tailings stored in TD basins under undrained conditions. Illustration of the cyclical mobility and liquefaction cases, where a material under dilatant conditions, b material under contractive conditions $\left(\tau_{0}<S_{u}\right)$, c material under contractive conditions $\left(\tau_{0}>S_{u}\right)$, d critical state line, e stress-strain response of a saturated, contractive sandy soil, under static and cyclic loading, $\mathbf{f}$ shear stress during earthquake. In the e image the left plot refers to shear loading and the right plot to normal loading. $\tau$ is shearstress resistance of the material. $\gamma$ is shear strain. $\tau_{0}$ is initial shearstress resistance of the material, due to permanent - gravitationalloadings. $S_{u}$ residual shear stress. $\mathrm{S}_{\mathrm{u}(\text { yield })}$ is yield shear strength. $\mathrm{S}_{\mathrm{u}(\mathrm{LIQ})}$ is liquefied shear strength (a-d adapted from Oldecop and Rodríguez 2006; and e adapted from Olson and Stark 2003) 
database suitable for assessing the main TDs failure mechanisms at a representative 67 of the 610 TD sites existing in Spain (Rodríguez and Gómez de las Heras 2006; Fig. S-1, Table S-1). These included large dams (which according to ICOLD (2001) and Rodríguez and Gómez de las Heras (2006), must meet at least one of the following requirements: $>15 \mathrm{~m}$ high, storing a volume $>$ one million $\mathrm{m}^{3}$, or $>500 \mathrm{~m}$ in length. The TDs that we studied included sites that have presented geotechnical stability problems (local slope failure, liquefaction, or liquefaction and flow failures) and were associated with a wide range of ore (Figs. 1,2).

\section{Materials and Methods}

\section{Mapping}

The inventory and cartography of TDs were carried out according to Macho et al. (2014). Their topography was based on LIDAR (IGN 2020), aerial photography (1928, 1956, 2006), satellite images, Google Earth satellite images, historical TD project documents, newspapers, magazines, accident reports, and technical reports. The natural materials of the foundation were mapped using the available geological map at 1:50,000 scale (IGME 2010) and by fieldwork. In TDs with landslides or FF, the original topography was reconstructed using the Free Software for Students and Educators (AutoCAD Autodesk 2020). Each TD map has a technical report that includes topography, a geological profile, physical characteristics (particle size distribution, particle density), and the tailings' mineralogical, chemical and basic geotechnical characteristics (Macho et al. 2014; Rodríguez 2006).

\section{Physical Characterization}

\section{Particle Size Distribution}

Different types of samples were used: surface samples $(1-20 \mathrm{~cm}$ ), boreholes, trenches, etc. (Table S-1, Fig. S-2). Particle size was characterised according to the ASTM $(1992,2009)$. The fine fraction was analysed by laser diffraction using the methods developed by Vitton and Sadler (1997) and Caparrós (2017). We used the laser method (ISO 2009), which is applicable to particle sizes ranging from $\approx$ 0.001 to $3 \mathrm{~mm}$.

\section{Particle Morphology}

We used a scanning electron microscope (SEM) to verify the variability of particle shapes in a single TD. Two $0.5 \mathrm{~g}$ specimens of tailings (P9), some in situ unaltered tailings (Fig. S-2a), and liquefied and weathered tailings (W11; Fig.
S-2d) were collected by wet sieving between a nominal aperture size from 63 to $100 \mu \mathrm{m}$ (Filtra sieves, Barcelona, Spain), using purified water in a bottle with a hand-pumped sprayer. The particles were dried at $60^{\circ} \mathrm{C}$ overnight, and then gently spread over a double-sided adhesive copper conductive tape (Prod. 16074, TED Pella Inc., California, USA), sputtered coated with platinum for $120 \mathrm{~s}$ at $15 \mathrm{~mA}$ and $1.8 \mathrm{kV}$ in a SC7640 sputter coater (Quorum Technologies Ltd, Ashford, UK), and finally examined under a SEM (Hitachi S-3500 N, Japan).

\section{Geotechnical Characteristics}

Optimal water content was measured using a moisture-density relationship test, laboratory soil compaction characteristics, or simply a standard Proctor test, as detailed in ASTM D698 and AASHTO T 99 test methods (ASTM 2006a). We used the oedometer test method (ASTM 1992, 2006b, 2019; Rodríguez 2002, 2006b) to measure consolidation.

The cone penetration test (CPT) trials were carried out using the ASTM D1586/D1586M-18 ASTM (2006c) methodology. The data used for the analysis respond to different TDs, at different conditions and depths. Direct shear of remoulded and unaltered samples of mine tailings were measured according to ASTM D3080/D3080-04/ D3080M-11 ASTM (2006c; d, e).

Experiments were conducted to define the compaction behaviours of saturated tailings, but completely drained, sand- and silt-sized tailings samples were studied in response to repeated cycles of shear strain, using the methodology developed by Youd (1972). The frequency of straining was one cycle per four minutes. The velocity was $0.5 \mathrm{~mm} / \mathrm{min}$. The tests were performed for three vertical strains $(1,2$, and $3 \mathrm{~kg} / \mathrm{cm}^{2}$ ). Shear displacement and vertical changes were continuously monitored. The effects of vertical stresses, void ratio, and particle size distribution were also determined. This test is important because TDs are subjected to a large number of cycles of shear strain during their long life due to the effect of low, medium, and high seismic activity, machine traffic, blasting, landslides, etc. In addition, tailings are subjected to increasing vertical loads due to the addition of new tailings and water.

\section{Mineralogical and Physicochemical Characteristics}

The mineralogical and physicochemical characteristics of tailings samples and efflorescences were determined using the methodology of Alcolea et al. (2012, 2015). Major, minor, and trace elements were all determined. The chemical composition of solids was determined by $\mathrm{x}$-ray fluorescence (Alcolea et al. 2010). 


\section{Hydraulic Characteristics}

\section{Saturated Hydraulic Conductivity}

Saturated hydraulic conductivity was measured in situ in 10 TDs using the Lefranc methodology (ASTM 2006c; CAN/BNQ 2008). The Lefranc method is particularly suitable for soils with hydraulic conductivities exceeding $10^{-7} \mathrm{~m} / \mathrm{s}$. The saturated hydraulic conductivities of remoulded and unaltered samples were also measured in the laboratory, using the methodology developed by Rodríguez et al. (2006a, b).

\section{Water Retention Curve (Osmotic and Matric Suction)}

Tailings water characteristic curves or water retention curves (WRCs) were obtained using different experimental techniques depending on the suction range being considered and materials (Dimos 1991). A sample of waste mixed with distilled water at a particular density and water content was prepared (see methodology developed by Rodríguez 2002, 2006b). We measured the osmotic suction of three different mine tailings and two types of salt efflorescence, using the methodology developed by Firmana and Schanz (2009).

The value of water suction in the soil pores, in equilibrium with a humid air environment, is thermodynamically linked to the relative humidity of the environment. Kelvin's Law relates the two:

$h_{r}=e \frac{-M w \times s}{R \times T}$

$e=\frac{n}{1-n}$

where $h_{r}$ is relative humidity, Mw is molecular weight of water $(0.018 \mathrm{~kg} / \mathrm{mol}), s$ is suction $(\mathrm{MPa}), R$ is universal gas constant $\left(8.314310^{-3} \mathrm{MPa} \mathrm{kg} /{ }^{\circ} \mathrm{Kmol}\right), T$ is temperature $\left({ }^{\circ} \mathrm{K}\right)$, $e$ is the void ratio, and $n$ is the porosity of the porous media, with value between zero and one.

\section{Capillary Height}

The capillary height $\left(\mathrm{h}_{\mathrm{c}}\right)$ was determined by using the void ratio and particle size, per Terzaghi and Peck (1996):

$\mathrm{h}_{\mathrm{c}}=\frac{2 T_{s}}{\gamma_{w} e D_{10}}$

where $T_{s}$ is the surface tension of the water at room temperature $(=0.0742 \mathrm{~N} / \mathrm{m}), \gamma_{w}$ is the water density $\left(9807 \mathrm{~N} / \mathrm{m}^{3}\right)$, $D_{10}$ is the value representing the diameter at which $10 \%$ of the sample's mass is comprised of particles with a diameter less than this value.

\section{Specific Yield of Tailings}

The specific yield of the tailings samples was determined using the methodology developed by Johnson (1967), who used the soil classification triangle to show the relationship between solid particle size and the specific yield of the aquifer. He used lines with equal value of specific yield for 1 and $5 \%$ and classified the tailings into sand (2-0.0625), silt (0.0625-00.4), and clay ( $\geq 0.004)$, though we used $2 \mathrm{~mm}$ for the clay particle, per ISO (2009).

\section{Saturated and Drainage of Mine Tailings: Wetting and Drying Process Due to Interaction with Atmosphere}

The experimental saturation and evaporation drying process of a column of tailings was carried out using the methodology developed by Rodríguez et al. (2007). We used time domain reflectometer (TDR) sensors to measure the volumetric water content $(\theta)$. Knowing $\theta$, the void ratio $(e)$, density of solid particles $\left(G_{s}\right)$ and water content $(w)$ is possible to determine the degree of saturation $\left(S_{r}\right)$ (Rodríguez et al. 2004, 2006a, b).

$S_{r}=\frac{w G_{s}}{\gamma_{w} e}$

\section{Geophysics}

We used electrical resistivity imaging (ERI) per MartínezPagán et al. (2009, 2011) and Zarroca et al. (2015). We calibrated the ERI results with a resistivity lab test using a Geotek multisensor core logger (Cande and Kent 1995), and gravimetric water content and $S_{r}$ per Rodríguez (2006). Boreholes were developed in different TDs. Tailings samples were collected at $1 \mathrm{~m}$ intervals from some foundation materials according to the depth profile and 0,10 , and $20 \mathrm{~cm}$ in surface. The samples $(2 \mathrm{~kg})$ were stored in plastic bags, preserved, and sent to the laboratory for physical, mechanical, mineralogical, chemical analysis, and environmental risk evaluation (Alberruche et al. 2016; Macho et al. 2014).

\section{Geotechnical Stability Analysis}

The safety factors were calculated using a coupled hydromechanical fine element formulation for different boundary conditions (Slide, Rock Science www.rocscience.com), which includes the following calculation methods: the 
Fellenius (1927), simplified Bishop (1955), simplified Janbu (1954), Janbu corrected (1968), and GLE/Morgenstern-Price (1965) methods. The basis to use these methodologies is due to their modelling concepts and the methods showed agreement with proven analysis.

\section{Results}

\section{Tailings Dam Mapping and Characterization}

TDs are classified according to their operating status: active (Figs. 3, 4), abandoned (Figs. 5, 6) and restored (Fig. 5, Table S-1). In addition, some tailings are discharged as they leave the flotation process and are separated by gravity when flowing inside the TD basins, while other tailings are discharged after separation of the coarse fraction (sandsized) from the fines (silt-sized) by cyclones. The fines also undergo a gravimetric segregation process inside the TDs basin. Figures 3 and 4 show the spatial-temporal evolution on the surface of the position of the settling lagoon and the area affected by evaporation and discharge into two active TDs.

The TD shown in Fig. 3 stores the tailings derived from the flotation of sulphidic minerals from $\mathrm{Cu}$ extraction. Figure $3 \mathrm{a}-\mathrm{d}$ show the varying position of the lagoon and the areas exposed to evaporation, as well as the precipitation of efflorescence. Leaks are shown in Fig. 3e. Figure 3f shows the existence of a water table $1.4 \mathrm{~m}$ from the surface. This shows that the TD basin is completely saturated. In addition, the existence of thin stratification layers can be observed (Fig. 3f).

The TD in Fig. 4 stores tailings derived from aluminium extraction. It shows how the position of the lagoon and the evaporation area have frequently changed (Fig. 4a-d). In 2017 , a water lagoon covered more than $80 \%$ of the surface of the TD basin. We observed that the efflorescence dissolved when the humidity increased. The green colour of the vegetation was due to restoration of the dam (Fig. 4d).

Figure 5 shows a TD abandoned more than 50 years ago, which stores $\mathrm{Pb}-\mathrm{Zn}$ tailings from a sulphide-rich deposit (Table S-1). Its geotechnical stability has been affected by actions such as the construction of a drainage trench inside the basin and in the dam (Fig. 5b-d). Actions that fail to consider the proper conceptual model of operation must be amended, which entails an additional expense to restore the TD (Fig. 5d). Disharmonic sedimentary structures, consisting of a fold that resembles an inverted depressed $\mathrm{V}$ in crosssection, can be seen (Fig. $7 \mathrm{~g}$ ).

Spatial-temporal evolution of an abandoned TD with different processes: liquefaction and FF, an area affected by released tailings, drainage network, gullies, and piping due to hydric erosion, is shown in Fig. 6. Evidence of stratification and important concentrations of efflorescence on the
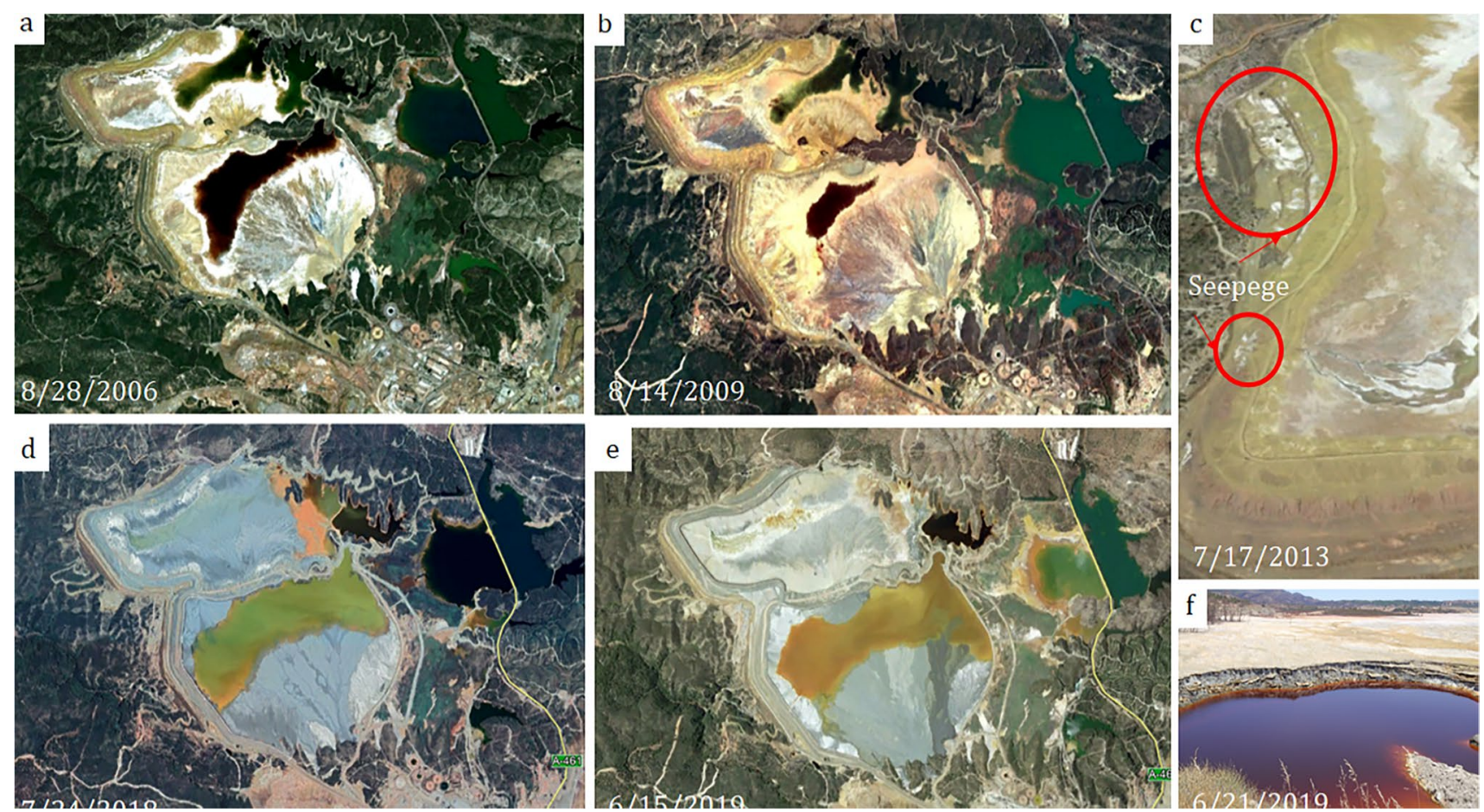

Fig. 3 Spatial-temporal evolution of an active TD with important concentration of efflorescence on surface. Storage tailings due to flotation process for extraction of $\mathrm{Cu}$, Minas de Rio Tinto, Spain 

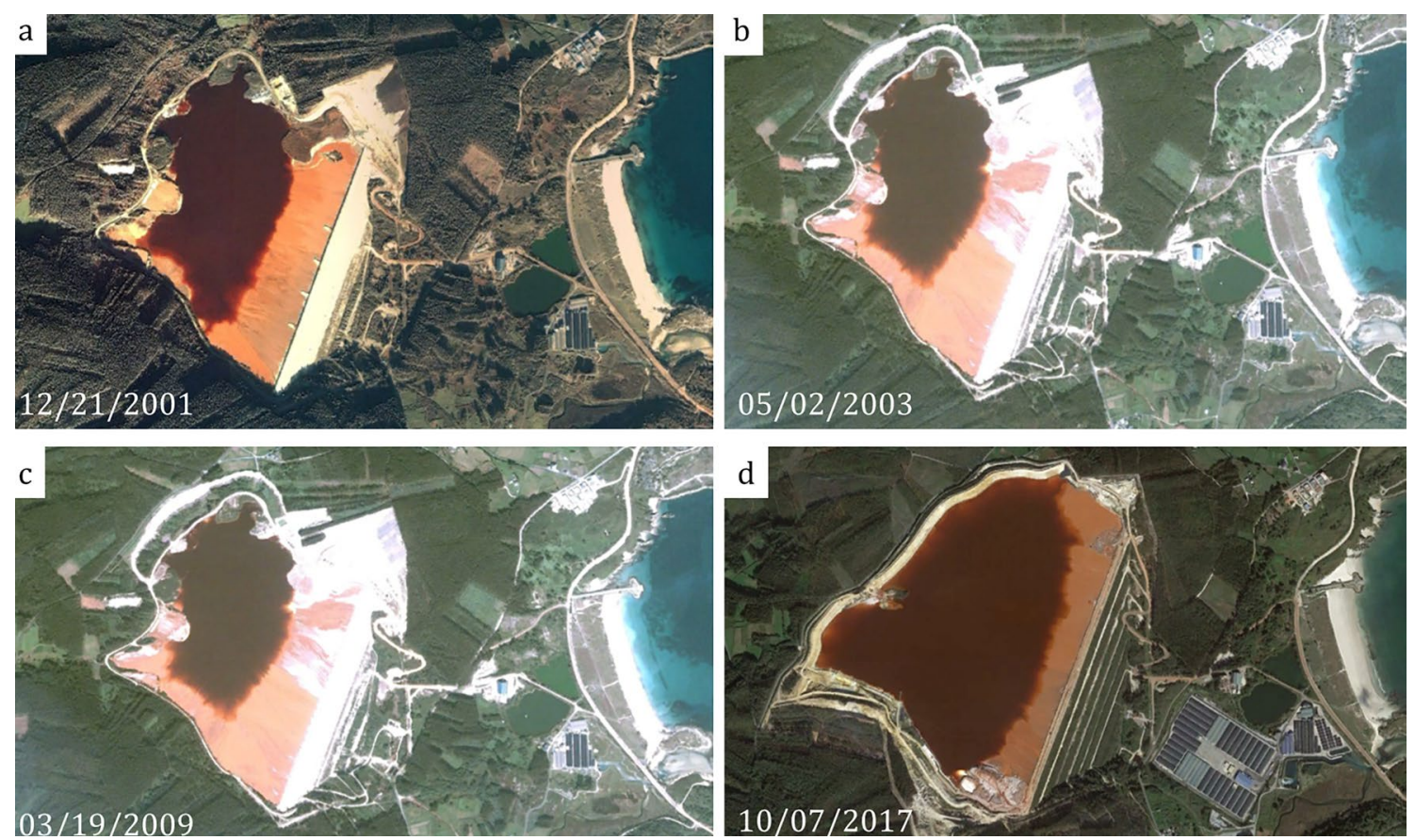

Fig. 4 Spatial-temporal evolution of an active TD with important concentration of efflorescences on the surface. Storage tailings due to the Bayer process of extraction of Al, San Ciprian, Galicia, Spain
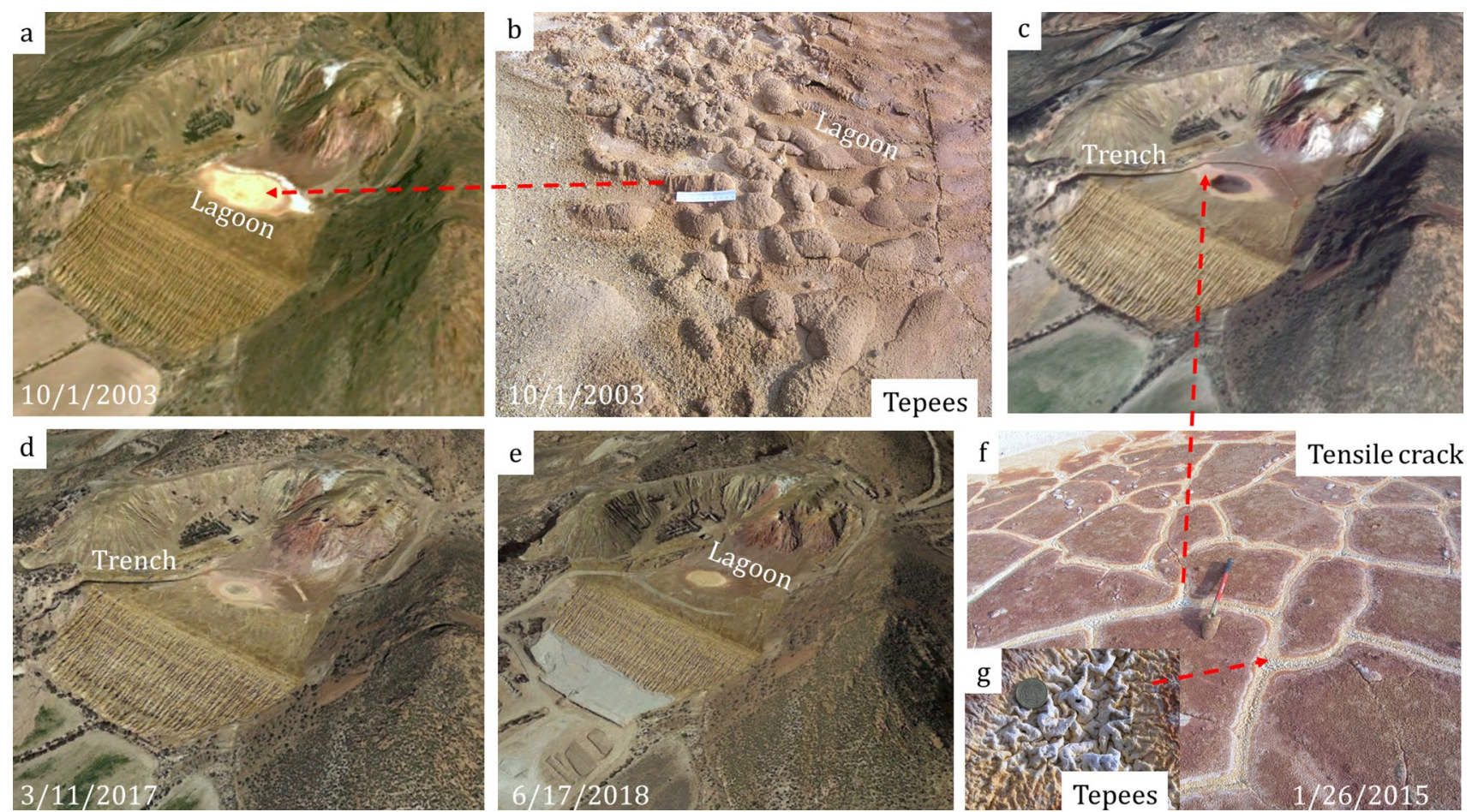

Fig. 5 Spatial-temporal evolution of an abandoned tailings dam with important concentration of efflorescences on the surface a dry lagoon and efflorescence, $\mathbf{b}$ construction of a drainage trench, $\mathbf{c}$ the drainage trench caused the development of tensile cracks and important hydric

erosion process, $\mathbf{d}$ sealing of the drainage ditch and construction of a wall at the base of the dam e detail of crust efflorescence, $\mathbf{f}$ detail of tensile cracks, $\mathbf{g}$ detail of efflorescent crust. Cerro de San Cristóbal. Mine district Mazarrón, Murcia, Spain 

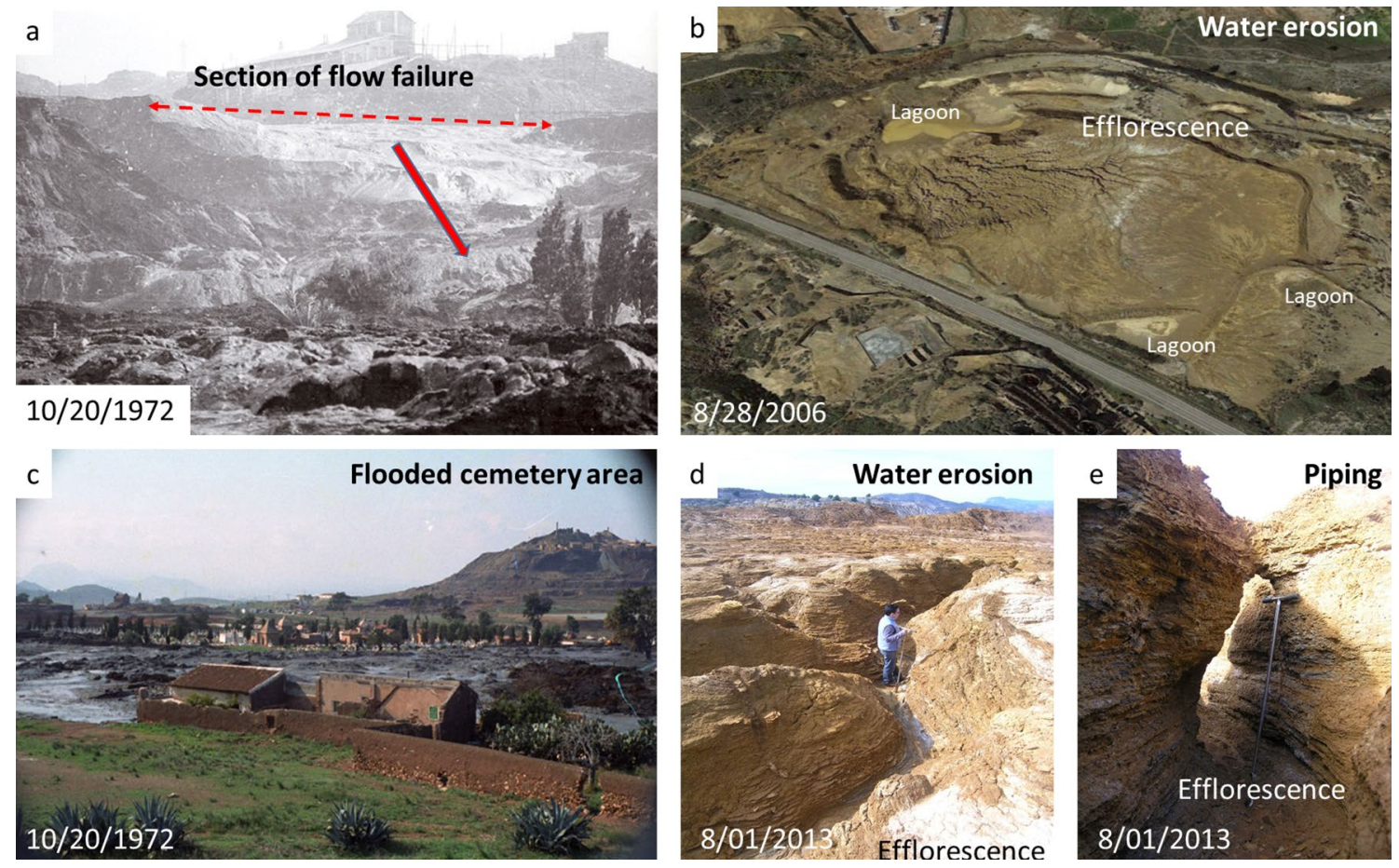

Fig. 6 Spatial-temporal evolution of an abandoned tailings dam with different processes: a liquefy and flow failure, $\mathbf{b}$ cemetery area affected by flow failure, $\mathbf{c}$ panoramic view of the drainage network due to water erosion, $\mathbf{d}$ gullies due to hydric erosion, e piping. It can

be observed an important concentration of efflorescence on surface (b, d, e). Tailings dam Brunita. Mine district Sierra de Cartagena-La Unión, Murcia, Spain

Fig. 7 a Restored tailings dam with storage-release covered with soil, $\mathbf{b}$ efflorescence on surface of the dam due to seepage, $\mathbf{c}$ detail of the vertical profile. Tailings dam Llano del Beal, Mine District Sierra de Cartagena-La Unión, Murcia, Spain
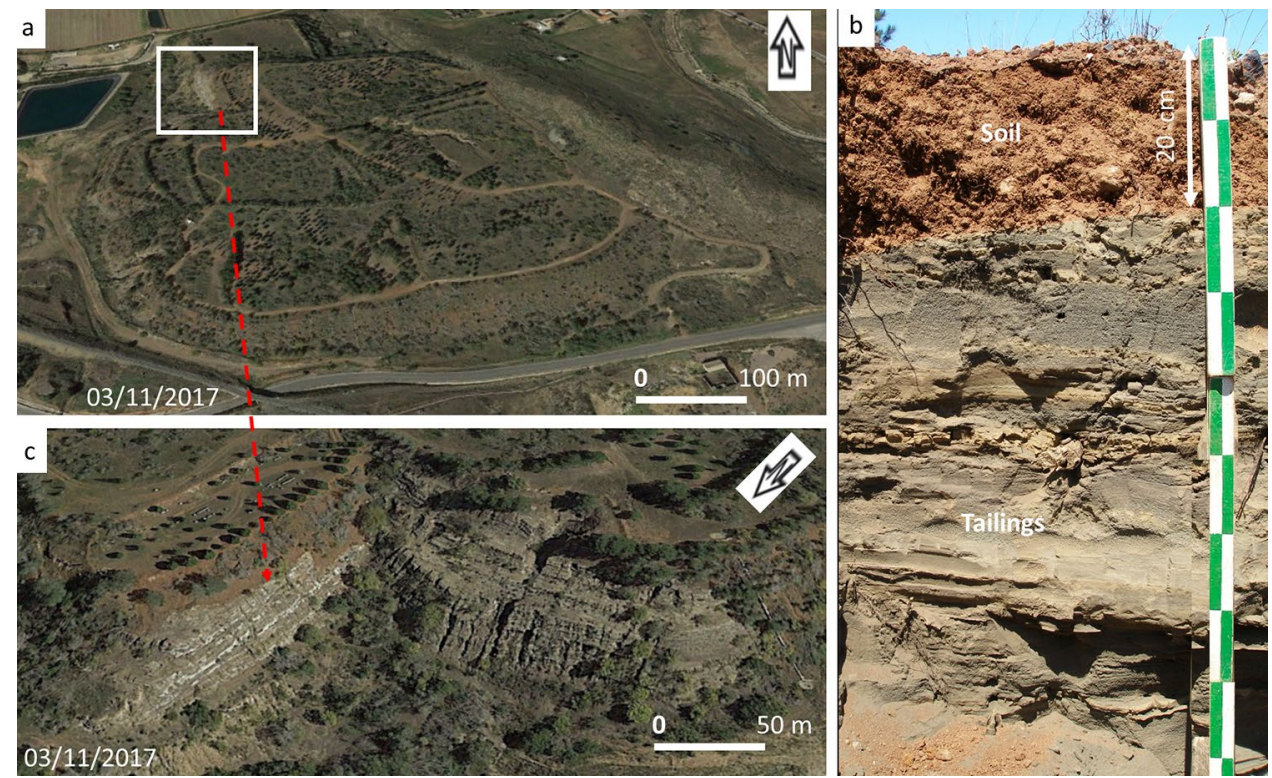

surface (Fig. 6b-e) can be observed. Figure 8b shows three zones of water accumulation during rainy periods.

There were several common processes in four of the studied TDs (Figs. 3, 4, 5, 6): (1) the settling lagoon's location and size periodically changed; (2) surface areas undergoing evaporative drying processes changed seasonally; (3) the surfaces exhibited efflorescence; and (4) mineral crusts resulting from weathering, oxidation, and precipitation processes were present. Cementation of secondary minerals derived from 

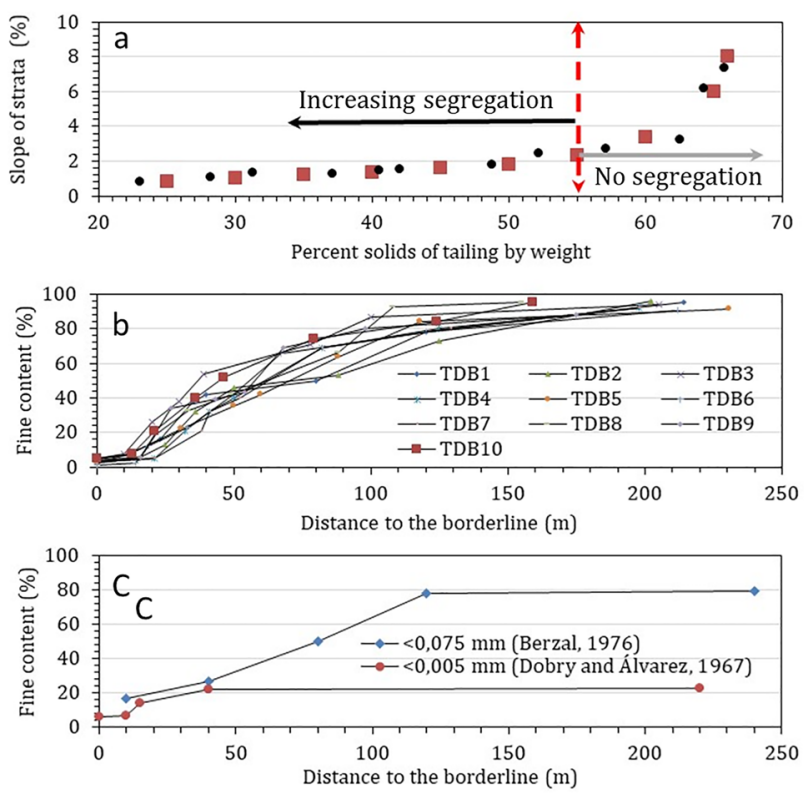

Fig. 8 a Influence of the concentration of solids on the segregation of the particles and the slope of the layers, $\mathbf{b}$ particle segregation can be observed following the flow direction inside the TDs basin, $\mathbf{c}$ results obtained in other research works

physical-chemical-biological weathering processes can also occur, since all of the dams have seepage issues, stratification, drying cracks, etc. (Figs. 3, 6). Weathering and cementation are favoured by the typical practices of recirculating process water and discharging infiltration waters recovered from piezometers or drainage systems back into TD basins.

In active TDs, the discharge of the tailings to the lagoon (Figs. 3, 4) create a flow along the beach, with the coarse sedimentation fractions settling near the point of discharge and the rest being sorted by size with the distance travelled. The finest fraction goes to the settling lagoon where it settles under a water layer of variable depth. The evolution of the degree of saturation (humidity) of the tailings, after the discharge, depends mainly on its particle size distribution, the position of the lagoon and the water table level inside the TD basin. Figure 8a shows the influence of the concentration of solids on the segregation of the particles and the slope of the layers. Segregation of the particles was confirmed by sampling of horizontal profiles in 10 of the TD basins (Fig. 8b). These results are consistent with previous studies (Berzal 1976; Dorby and Álvarez 1967; Fig. 8c). According to the physical, mechanical, hydrogeological, and sedimentary characteristics of the TDs, four zones can be distinguished: dike zone (Z1), discharge zone (Z2), transition zone (Z3), and distal zone or lagoon. The position and limits of these zones depends on changes in the point of discharge and where the water enters the TD (Fig. 8).

\section{Stratification in TD Basins}

The tailings can be cohesive or not, but their physical properties are distinct from those of the original rock source. Their sedimentation and stratification are complex due to continuous changes in the discharge point features, volume of discharge, solids concentration, particle size distribution, TD area, environmental conditions, and chemical composition of the water. We observed stratification in all of the studied TD basins. Strata are relatively thick $(0.1-30 \mathrm{~cm})$. Analogous sedimentary structures to strata formed in natural sedimentary basins were observed in the TD basins (anthropogenic sedimentary basin) (Fig.
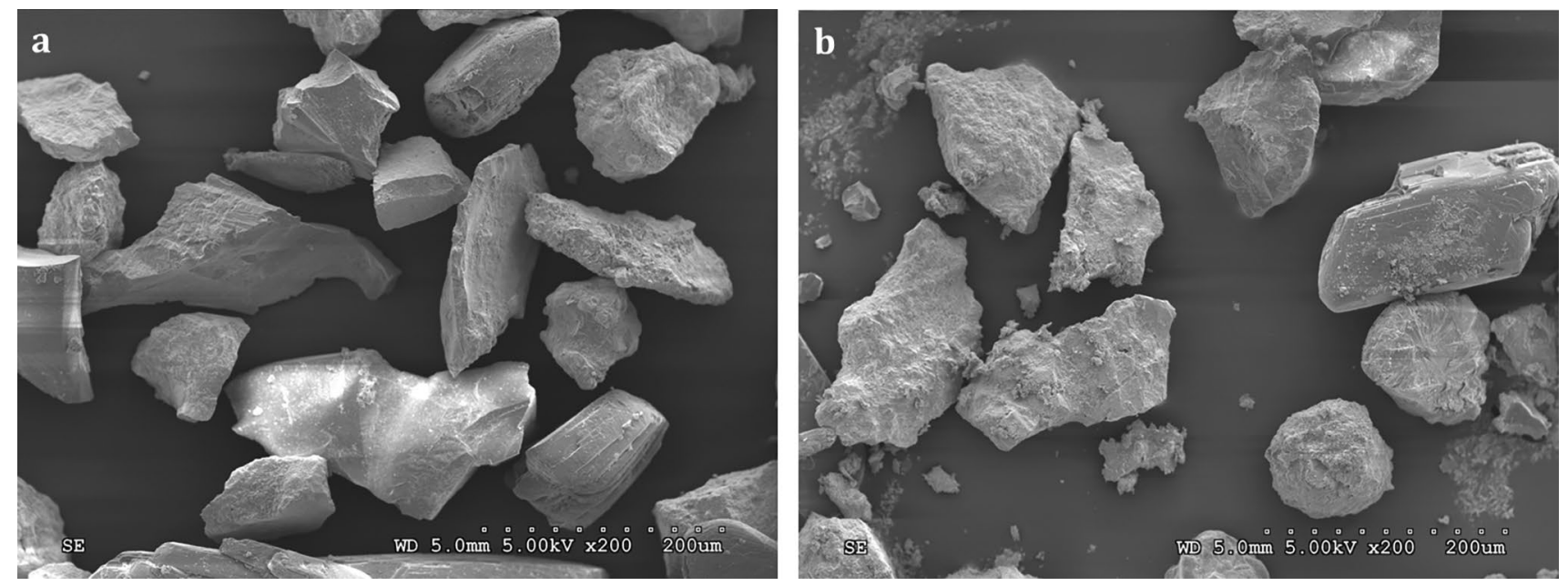

Fig. 9 SEM images of 63-100 $\mu \mathrm{m}$ particle size, coming from "El Descargador" TD (scale bar: $200 \mu \mathrm{m}$ ): a specimen W11, collected from the sand dike from bottom to top on the surface of landslide $\mathbf{b}$ Specimen P9, collected from the trial-pit profile 
S-3). Stratification is very common in tailings dam basins (Dobry and Alvarez 1967; Rodríguez et al. 2011; Smith 1969, 1973).

\section{Physical Characteristics of Mine Tailings}

The physical properties of tailings derived from flotation processes for metal extraction vary widely horizontally and vertically. We measured the different physical and mechanical properties of the solidified tailings in 28 boreholes from 17 TD basins. The grain size distribution is shown in Fig. $\mathrm{S}-4$. The grain size of most of the tailings was less than $1 \mathrm{~mm}$, averaging $0.2-0.02 \mathrm{~mm}$. The in situ dry density oscillated between 1.1 and $1.8 \mathrm{~g} / \mathrm{cm}^{3}$. The solid particle density varied between 2.3 and $3.02 \mathrm{~g} / \mathrm{cm}^{3}$. The in situ void ratio ranged between 0.9 and 1.7. Gravimetric water content also varied (15-40\%), depending on the sample's position in the vertical or horizontal profile (Fig. 8): highest in the silt-clay materials in the settling lagoon and lowest in the sand strata near the tailings discharge zone. The liquid limit ranged between 40 and 44, and the plastic limit between 36 and 40 . The presence of little or no clay minerals resulted in low or null plasticity index values. The tailings had plasticity only when the fines content $>70 \%$. According to their grain size distribution, mine tailings can be categorized as sand or sandy silt. The predominant soil class is ML, following the United Soil Classification System (Fig. S-5). These physical characteristics are consistent with results in other tailings (Alonso and Gens 2006; Caparrós 2017; Garino 2018; Lloret et al. 1999; Okusa et al. 1980; Rodríguez 2006; Rodríguez et al. 1998, 2006b, 2011).
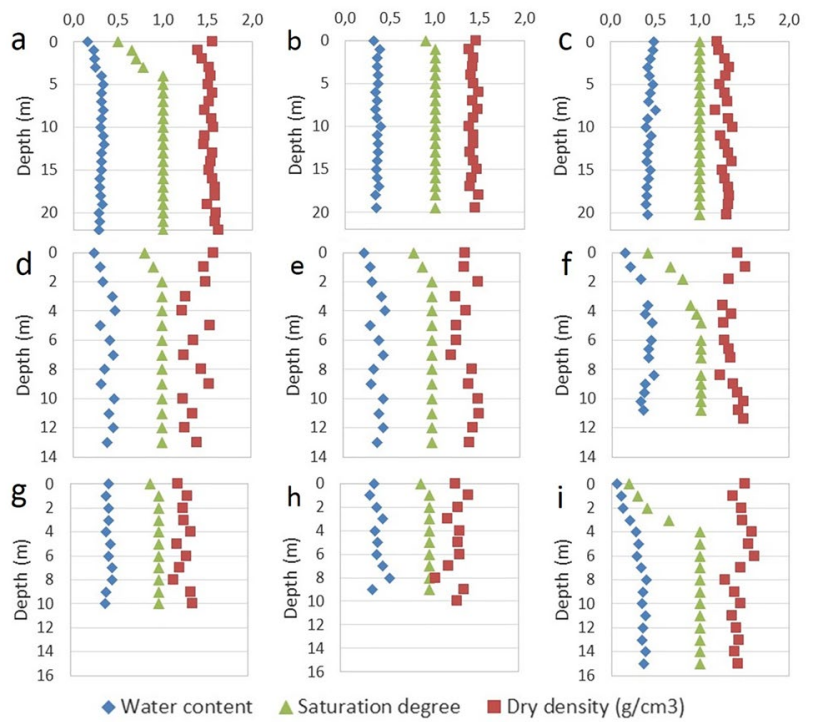

Fig. 10 Water content, degree of saturation and dry density in different TDs: a TD1, b TD2, c TD3, d TD4, e TD5, f TD6, g TD7, h TD8, i TD9 (Table 1)

\section{Particle Morphology}

The mine tailings particles from the "El Descargador" TD exhibited very different shapes when observed with the SEM (Fig. 9), depending on their degree of weathering and liquefaction. Figure $9 \mathrm{~b}$ shows an image of sample $\mathrm{P} 9$, a fine-grained material from the trial-pit profile. This mineralogically unaltered zone had maintained its original stratification since the tailings were discharged. In contrast, Fig. 9a (sample W11) was a coarse-grained material from the sand dike cutting through the surface of a landslide (Fig. S-4d). Therefore, it is a weathered postflotation waste with a history of liquefaction. Compare the irregularity of the unweathered particles of sample P9 with the rough surface of the previously liquefied and very weathered tailings in sample W11. This morphology is consistent with observations in other tailings (Alonso and Gens 2006; Lloret et al. 1999; Okusa et al. 1980; Rodríguez 2002, 2006b; Rodríguez et al. 1998).

\section{Degree of Saturation}

In active TDs, the solid tailings are sometimes fully saturated during rainy periods, but below the superficial crust, the degree of saturation varies according to the input of water. Inactive or abandoned TDs are generally saturated at the surface, especially in their lagoon areas (Figs. 3, $4,5,6,7)$, the lowest place on the surface of the TDs. The $\mathrm{Sr}$ of the solidified tailings in the cores from nine of these TD basins revealed that mine tailings at depths $>4 \mathrm{~m}$ remain almost saturated $(\mathrm{Sr}>90 \%)$, even after 50 years after being abandoned, despite semiarid climate conditions (Fig. 10, Table S-2). These water contents are consistent with results in other tailings dam (Alonso and Gens 2006; Lloret et al. 1999; Okusa et al. 1980).

\section{Geotechnical Characterization of Mine Tailings}

\section{Oedometer Test}

The oedometer tests measured the magnitude of consolidation strains of tailings samples for different vertical constant loads (Fig. 11a). The magnitudes of consolidation plotted against log time exhibit a clear decrease in the void ratio as the load increased from 0.1 to $12 \mathrm{~kg} / \mathrm{cm}^{2}$. Under these conditions, the tailings samples were saturated. Figure $11 \mathrm{~b}$ shows the results of 15 oedometer tests on remoulded and unaltered samples with different initial physical properties (Table S-3). The void ratios were plotted against a log effective stress (Fig. 11b). The initial value of the void ratio ranged between 1.14 and 0.53 . The compression index and the swelling index values obtained 


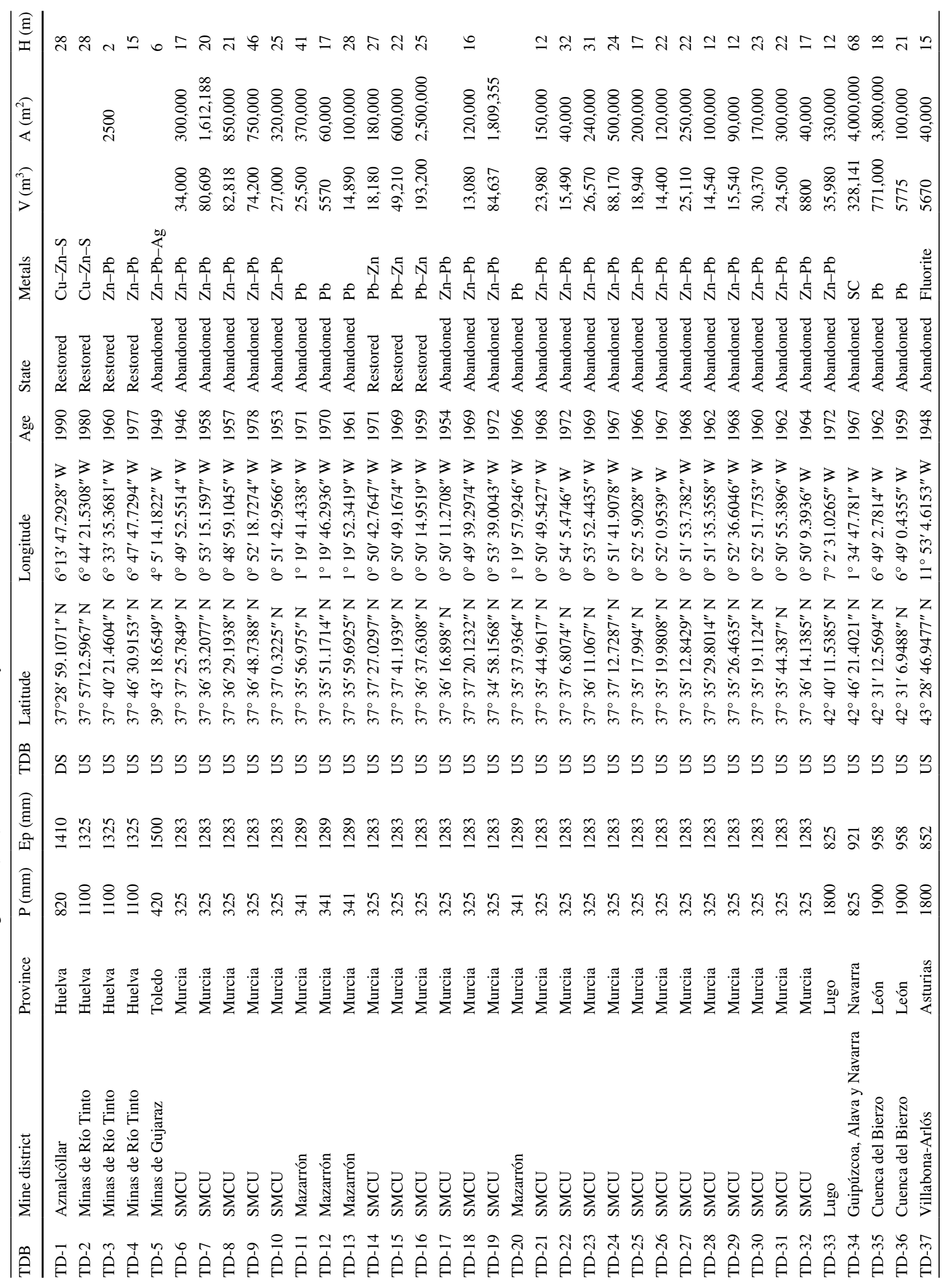




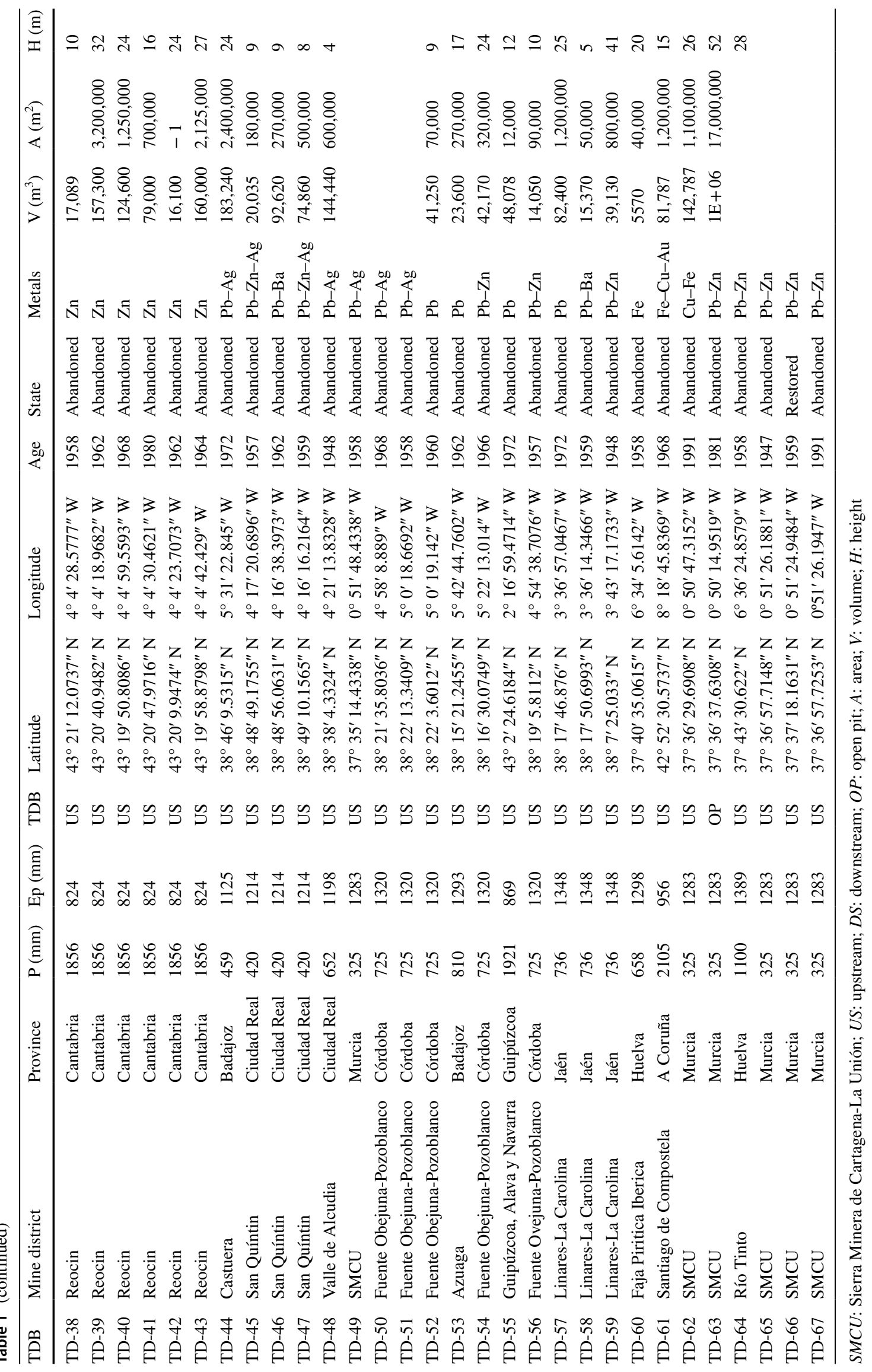




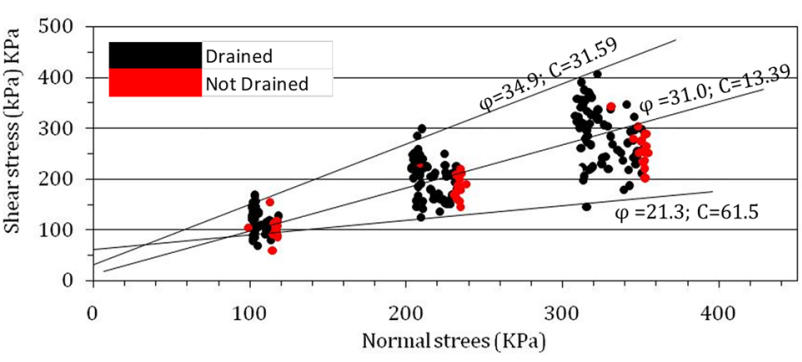

Fig. 11 Edometer results a consolidation and collapse of samples for different vertical load vs. time, $\mathbf{b}$ void ratio vs. vertical stress for unaltered and remoulded samples

also varied (0.1-0.24 and 0.02-0.05, respectively) (Table $\mathrm{S}-3)$. This behaviour is consistent with observations in other tailings with similar grain size distributions and porosity (Alonso and Gens 2006; Lloret et al. 1999; Okusa et al. 1980; Rodríguez et al. 1998; Rodríguez 2006).

\section{Direct Shear Test}

Figure 17 shows the results of shear stress vs. normal stress for 15 undisturbed tailings samples. Table S-4 shows the main characteristics of the samples used in the direct shear tests and the results of friction angle $(\varphi)$, cohesion, and plastic index. The observed internal friction angles varied widely (Fig. 12), but the internal friction angles were mostly less than $31^{\circ}$ in the undrained tests, which was generally less than in drained conditions. This behaviour is consistent with values obtained in other mine tailings with similar grain size distributions, porosity, and morphology in saturated conditions (Acosta et al. 2011; Alonso and Gens 2006; Lloret et al. 1999; Okusa et al. 1980; Rodríguez 2006; Rodríguez et al. 1998, 2011).
These results are very important, since in most TDs, the values of the internal friction angle of the tailings used for the geotechnical stability calculation $>31^{\circ}$ (Zandarín et al. 2009). The problem is that internal friction angle values are normally obtained in laboratory tests on remoulded samples or indirectly, from standard penetration (SPT), CPT, or CPTU tests (Fernández-Naranjo et al. 2015). The values obtained using remoulded samples are always higher than those of undisturbed samples, because the field test results represent an average value for an interval of $20 \mathrm{~cm}$ or more, without taking into account that this profile may have several layers of different physical, mechanical, and hydrogeological features.

\section{Cycles of Shear Strain}

Figure 13 shows the void ratio vs strain evolution of these samples cyclically strained in simple shear. Table $\mathrm{S}-5$ shows the main characteristics of the two tailings samples used to test responses for cycles of shear strain. During each strain excursion, the sample first contracted and then dilated; however, the consolidation was always greater than the dilation, so the net result was always an increasing density. Thus, sand- and silt- sized tailings can be compacted appreciably by repeated cycles of shear strain (Fig. 13). The amount of vertical strain, or compaction, accruing during a given number of cycles increases with shear strain magnitude and initial void ratio. The results show that if the tailings can drain, its compaction capacity increases and the TDs have more geotechnical stability. Also, the sand-sized tailings have higher consolidation (between 2.6 and 5.3\%) than siltsized tailings (between 1.3 and 2.0\%). In all cases though, the samples tend to collapse, despite their very small pore index.

Previously, Youd (1972) attributed this behaviour in sandy soil to the premise that less shear strain is required to collapse loose particulate structures than to expand dense
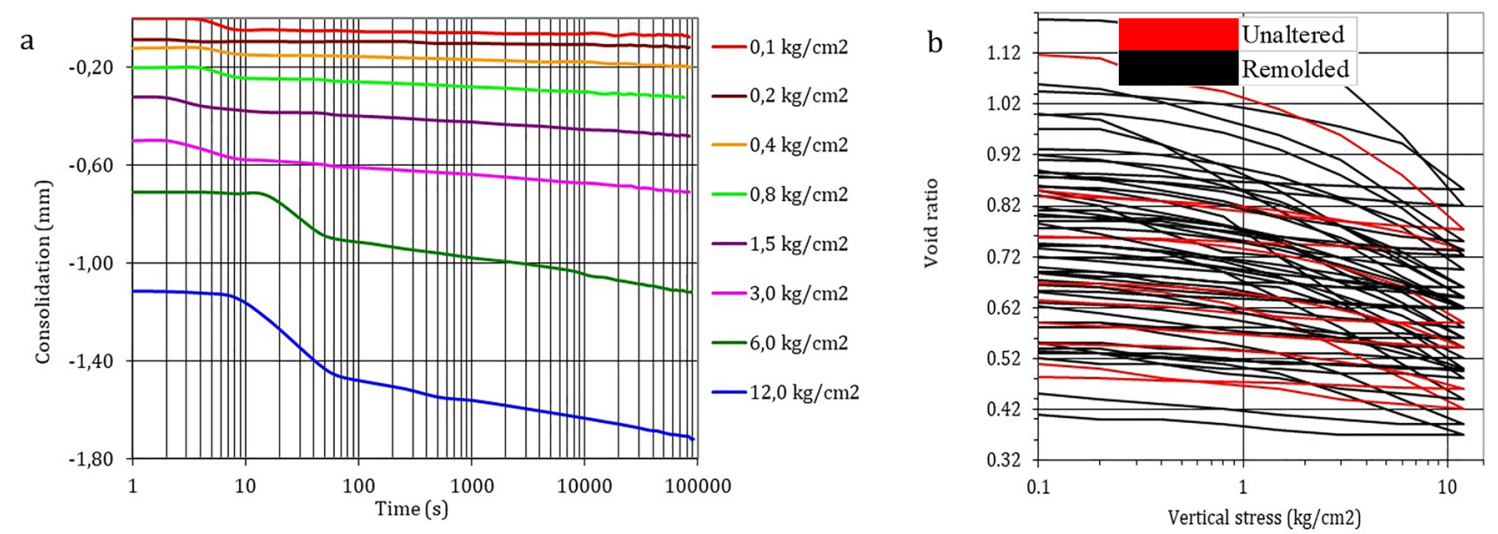

Fig. 12 Direct shear test results 
a

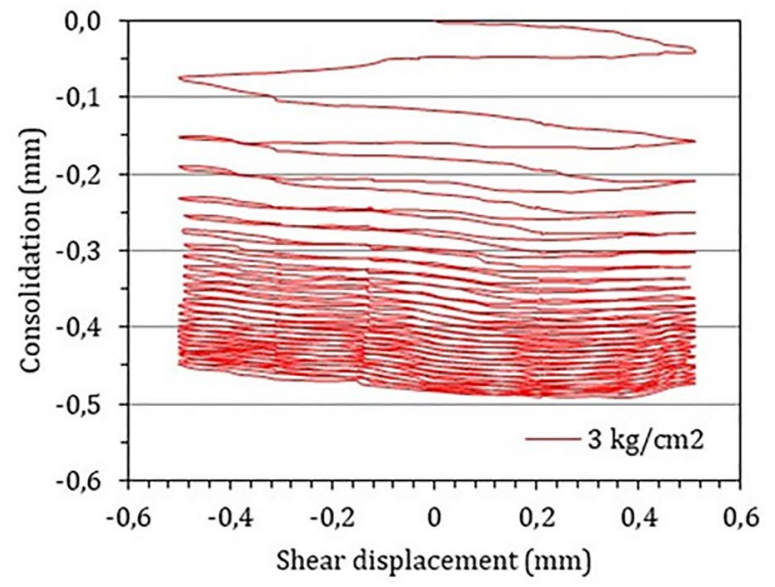

C

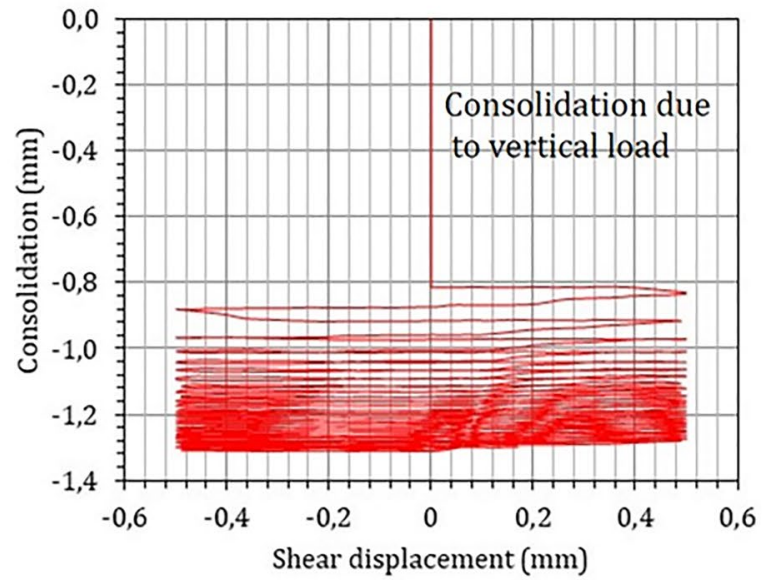

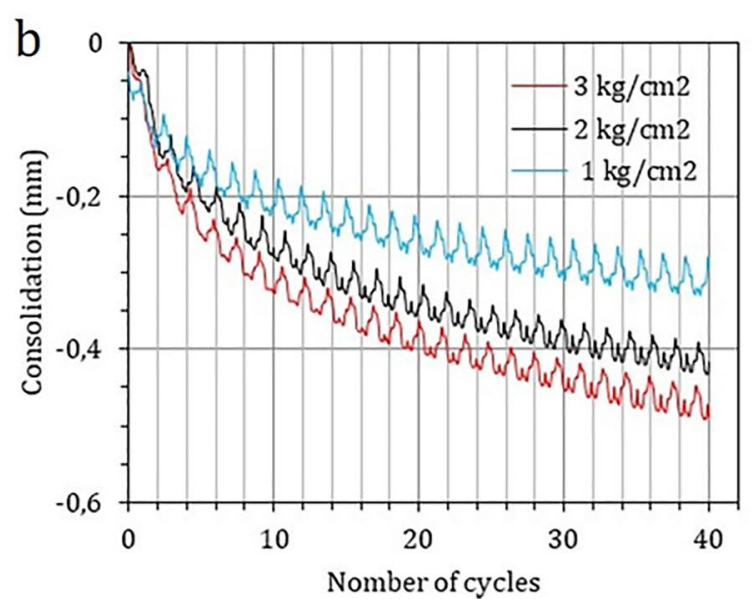

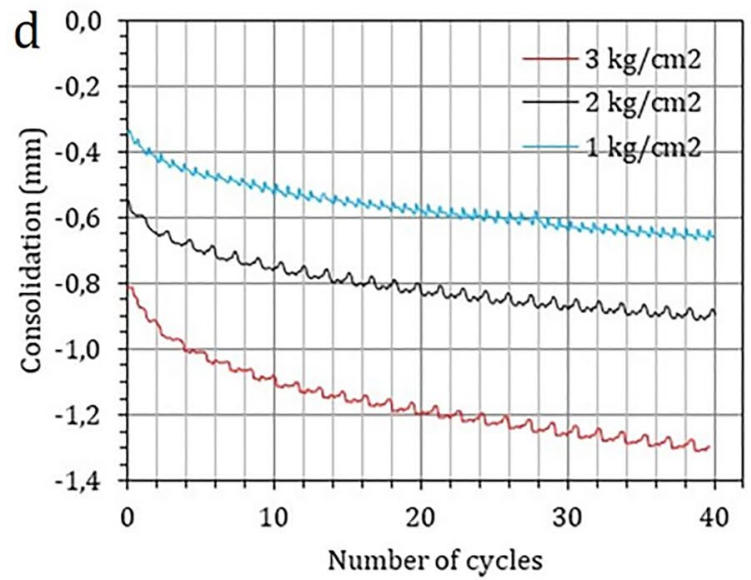

Fig. 13 Results of compaction versus shear-strain history of tailings samples at $3 \mathrm{~kg} / \mathrm{cm}^{2}$ and vs. number of cycles for 1,2 and $3 \mathrm{~kg} / \mathrm{cm}{ }^{2}, \mathbf{a}, \mathbf{b}$ is silt-clay tailings, $\mathbf{c}, \mathbf{d}$ is sand-silt tailings
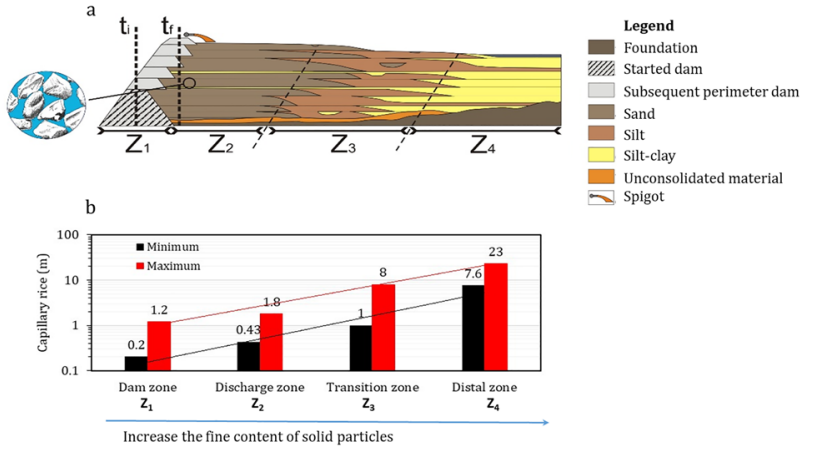

Fig. 14 Variation a capillary rise considering the different zones of the tailings dam basin. $Z_{1}$ is dam zona. $Z_{2}$ is discharge zone. $Z_{3}$ is transition zone. $Z_{4}$ is distal or lagoon or pond zone

ones, and that in a randomly packed system group, both types of structures exist. Another fundamental fact is that this type of behaviour (decreases in volume under cyclical deformation) ONLY occurs with non-plastic materials, that is: sands, silts or even gravel, but never in soils rich in clay minerals. This confirms the predominant non-plastic behaviour of the tailings (Table S-6).

\section{Hydrogeological Characterization of TDs}

\section{Capillary High}

The capillary rise in different zones or areas of the TD basin varied over almost two orders of magnitude between the dam and settling lagoon (Fig. 14). The capillary rise for six tailings samples from the $20 \mathrm{~m}$ tall "La Luciana" TD, calculated according to Eq. (5), using the $D_{10}$ values for each sample (Eq. 2). An average void ratio was calculated and utilised, as well as maximum and minimum values to comprehend the effect they have on the capillary rise. Note how the lowest $D_{10}$ value $(0.0009 \mathrm{~mm})$ of sample 2 , coupled with the lowest 


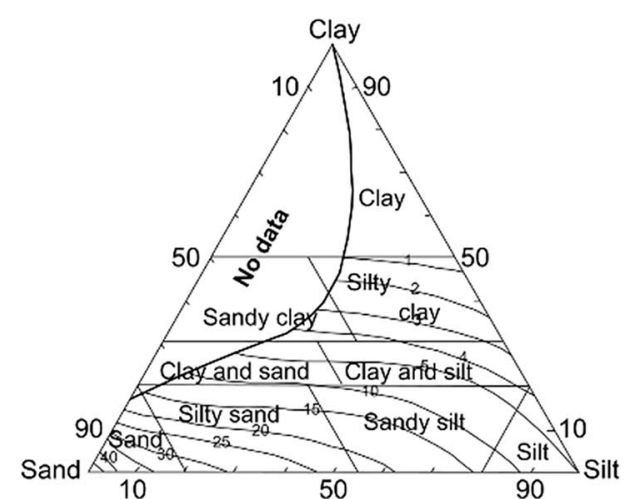

Fig. 15 a Soil classification triangle showing the relation between particle size distribution and specific yield of porous materials. Line of equal specific yield in percentage. Sand $2-0.0625 \mathrm{~mm}$, silt $0.0625-$

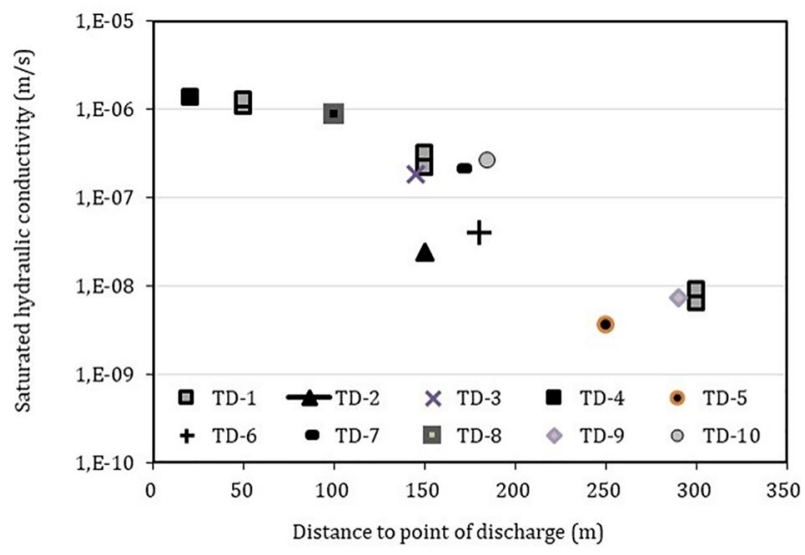

Fig. 16 Saturated hydraulic characteristics (k) vs. distance to the discharge point of tailings

(e) value $(0.77)$, offers a potential capillary rise exceeding the actual height of the TDs $(>20 \mathrm{~m}$ ) (Table $\mathrm{S}-7)$. If the dam was homogenously built as sample 2, the whole system would be completely saturated. However, TDs are complex and heterogenic structures, with observed capillary values of $0.38-20.35 \mathrm{~m}$ ). Capillary water cannot be drained by gravity and, furthermore, capillary height is not registered by piezometric instrumentation (Oldecop and Rodríguez 2006; Zandarín et al. 2009).

\section{Specific Yield of Tailings}

Figure 15 shows the relationship between particle size and the drainage or water delivery capacity of tailings. The quantity of water yielded to wells or piezometers from a body of saturated tailings depends on the specific yield of the tailings instead of its total porosity. Regular tailings have high porosity (40-70\%) and thus are capable of holding large amounts of water. However, they yield only a small portion of water

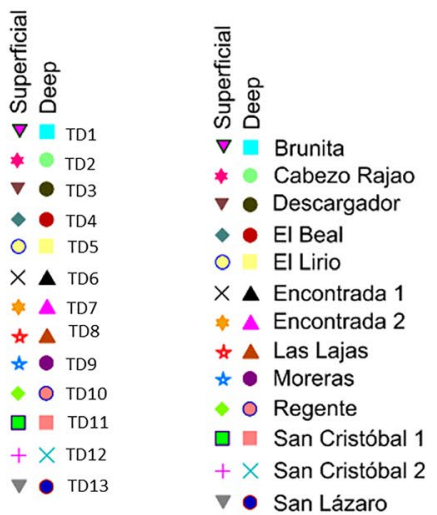

$00.2 \mathrm{~mm}$ and clay $<0.02 \mathrm{~mm}$. b Representation of the different TDs studied, post flotation wastes of $\mathrm{Pb}-\mathrm{Zn}$. Each colour represents different vertical profiles. "Triangle is adapted from Johnson (1967)"

under gravity drainage, even after a long period, due to the thin alternating layers of sand and silt. Consequently, the tailings layers remain saturated all along. It can be seen that the degree of saturation found in a vertical profile of $1 \mathrm{~m}$ of a TD is very high (Fig. 10). The clay fraction does not predominate in any study's tailings samples (Figs. 9, 15 S-4).

\section{Saturated Hydraulic Conductivity}

The saturated hydraulic conductivity in the vertical and horizontal profile of TDs varied over one to three orders of magnitude (Fig. 16). The saturated hydraulic conductivity magnitudes were less than that of an average natural aquifer. Therefore, tailings are considered a material with low or null drainage capacity due to the alternating sediment layers with different physical, mechanical, and hydrogeological properties (Figs. 9, 15, 16, S-4). These values are consistent with previous research on tailings dams (Alonso and Gens 2006; Kealy and Busch 1971; Okusa et al. 1980; Oldecop et al. 2011; Oldecop and Rodríguez, 2006; Rodríguez 2002, 2006b, 2018; Rodríguez et al. 2004, 2006a, b, 2011; Zandarín et al. 2009).

\section{Water Retention of Tailings and Sulphate Salt Efflorescence}

\section{Osmotic Suction}

Calibration tests show the existence of a linear relationship between electrical conductivity (EC) and osmotic suction (Fig. 17a). The osmotic suction in the solid mine tailings pore water has a very high value (Fig. $17 \mathrm{~b}, \mathrm{c})$ due to the large amount of salts in the pore fluids of the tailings (Table $\mathrm{S}-8)$. The maximum osmotic suction value in the borehole samples was found in the first $2 \mathrm{~m}$ due to capillary rise 

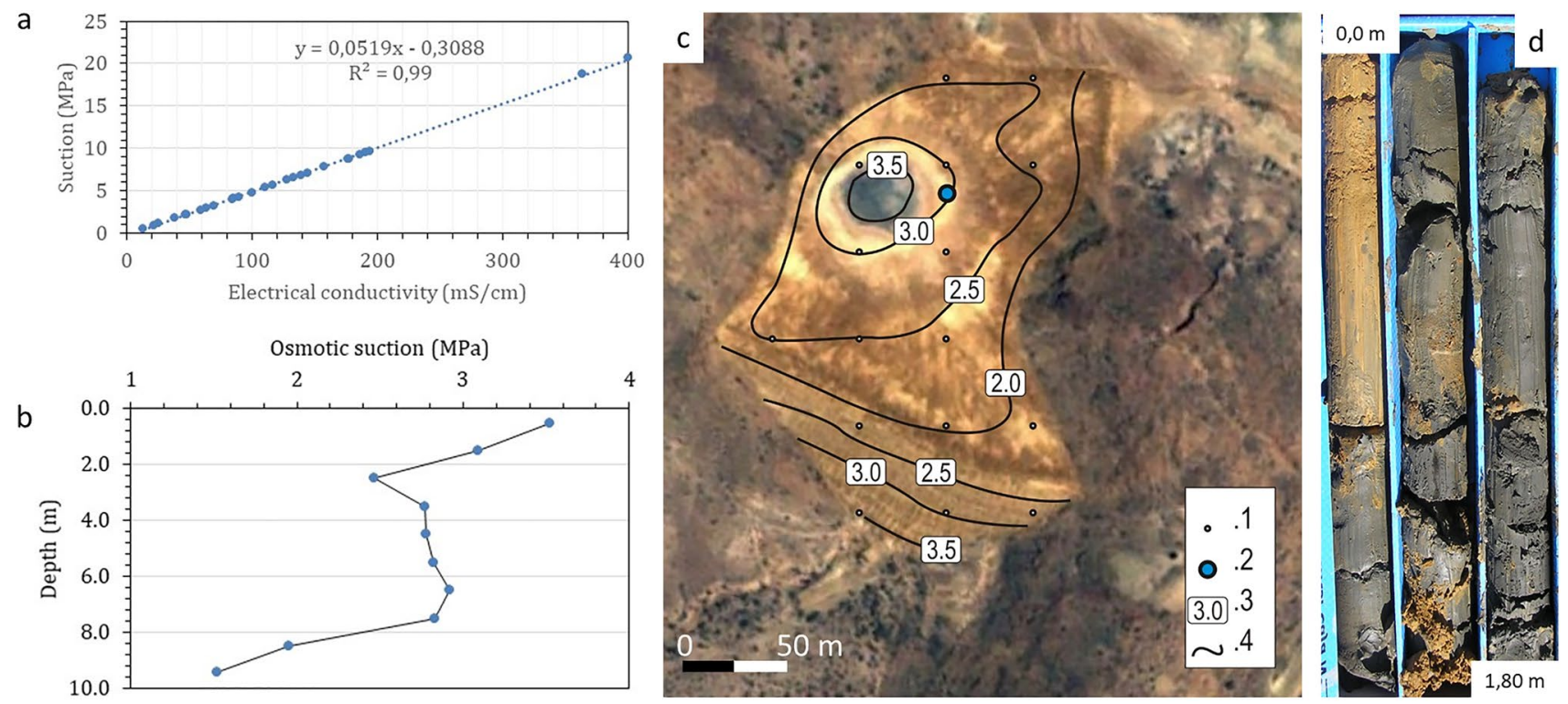

Fig. 17 a Calibration curve for determining osmotic pressure by means of electrical conductivity measurement of soil pore-water, b osmotic suction in a vertical profile, $\mathbf{c}$ osmotic suction in $20 \mathrm{~cm}$ depth

and drying and wet processes. In all cases the relationship between EC and osmotic suction at a depth of $20 \mathrm{~cm}$ was linear, independent of the water chemistry (Figs. 17a, S-6).

Osmotic suction was measured one day after a $10 \mathrm{~mm}$ rain in October 2018. The highest values were in the dam's settling lagoon. Horizontal, unsaturated groundwater flows through the dam (seepage), which, due to the water deficit $(900 \mathrm{~mm} /$ years in the Mazarrón mine district; Acosta et al. 2011) causes the precipitation of efflorescence on the surface (see white colour in Fig. 18), though sometimes it is not obvious due to being covered by wind-blown deposits of fine solid tailing particles.

\section{Water Retention Curve in Efflorescence}

Figure 19 shows the WRC corresponding to the wetting processes for two types of efflorescent samples with different physical, chemical and mineralogical properties (Tables S-9, S-10). The efflorescences are the result of the weathering of metallic sulphides, mainly pyrite, and the volcanic rocks in the TDs. As the gravimetric water content increases, the $\mathrm{Sr}$ suction decreases. The WRC shows the important change in the slope when suction $\geq 10 \mathrm{MPa}$ (Fig. 19c-f), for a value of 0.55 of the gravimetric water content (Fig. 19b, d). The WRC illustrates the effect of the high gravimetric water content.

Efflorescence adsorbs a lot of water due to its high porosity and adsorptive capacity. When the efflorescences are fully saturated, they present a suction value close to two $\mathrm{MPa}$, similar to the osmotic suction values in the tailings of tailings basin and dam (Legend: 1. Sampling point. 2. Borehole. 3. Osmotic suction value in MPa. 4. Isoline), $\mathbf{d}$ sample of borehole with diameter of $75 \mathrm{~mm}$ (TD-11, Mazarrón, Table 1)

pore water (Fig. 19c). The white efflorescent sulfate salts are rich in epsomite, has an alkaline $\mathrm{pH}$, and higher suction values while the yellow salts do not contain epsomite and have an acid $\mathrm{pH}$ (Tables S-4, S-5).

\section{Water Retention Curve (WRC) of Mine Tailings}

Figure 20 shows the WRC corresponding to the drying processes for three types of tailings samples with the same density but different sized solid particles (Table S-11). As can be seen in Fig. 18, suction increases as the tailings dry. The retention curve shows that the residual degree of saturation ranges approximately between 15 and $10 \%$. It also shows the effect of the particle diameter on the drying test WRCs. Reducing the particle diameter allows significantly more air to enter the tailings.

\section{Saturation and Drainage of Mine Tailings: Wetting and Drying Processes Due to the Interaction with the Atmosphere}

Figure 21 shows the experimental results of saturation and drying evaporation for a $0.32 \mathrm{~m}$ high and $0.30 \mathrm{~m}$ diameter tailings column. The characteristics of the sample are shown in Table S-12. The experiment was performed with controlled temperature and relative humidity during the day and night $(24 \mathrm{~h}$ ) for the 38 days of the experiment (Fig. 21a, b). The saturation process was controlled at three depths (Fig. 21d). The tailings took less than two days to become 

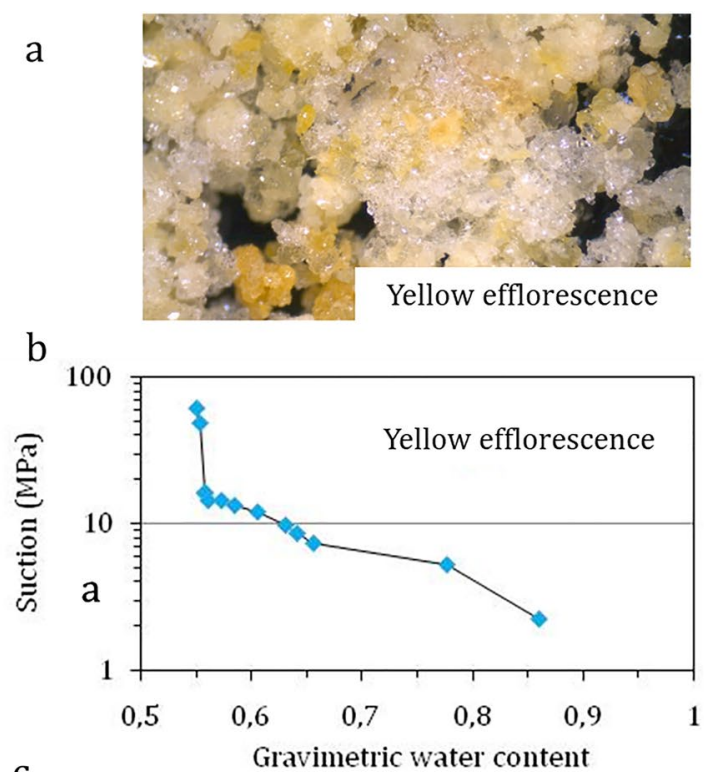

e
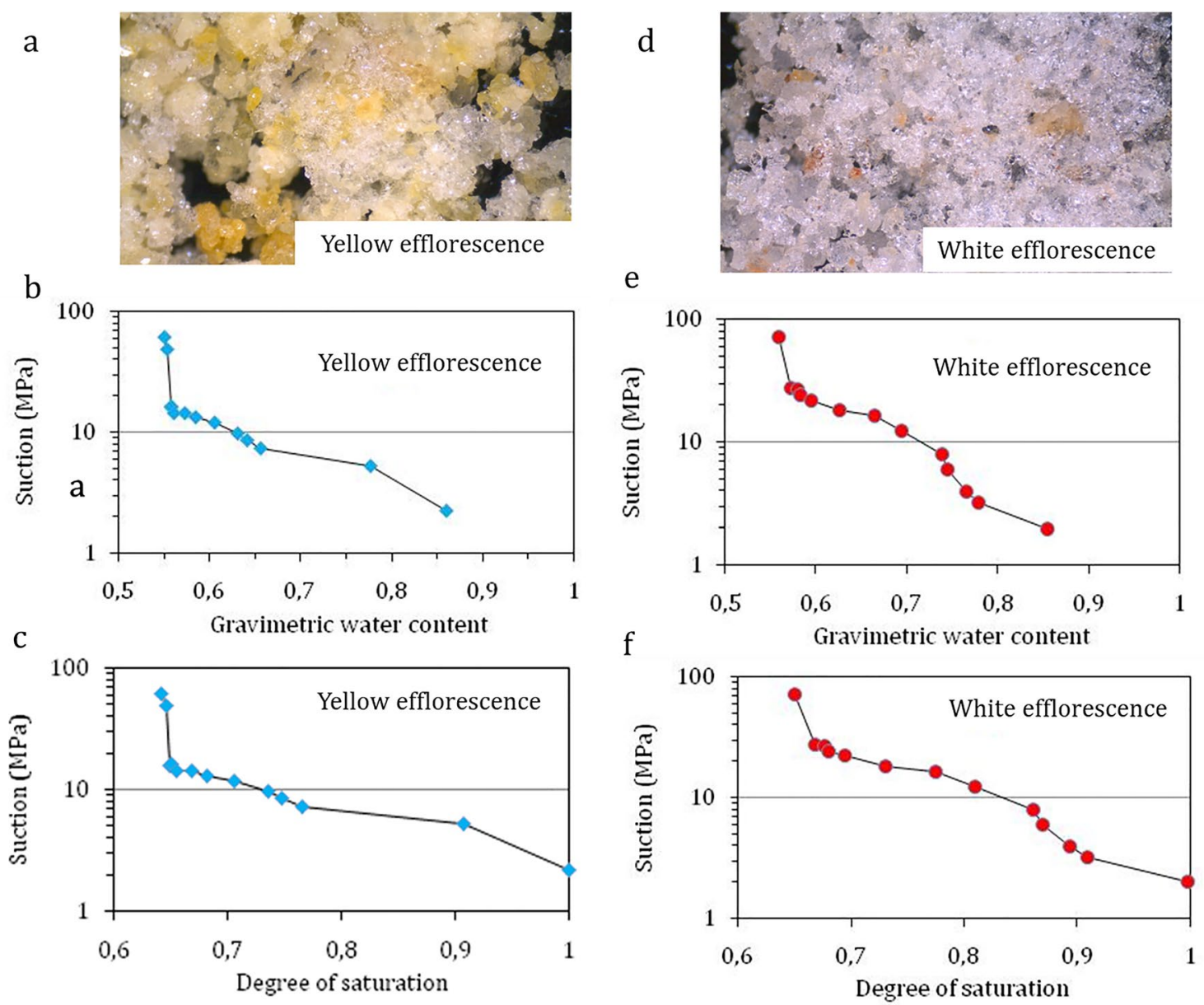

Fig. 18 Water retention curve in two types of efflorescences a yellow efflorescence image, $\mathbf{b}$ suction vs gravimetric water content, $\mathbf{c}$ suction vs degree of saturation, $\mathbf{d}$ white efflorescence image e suction vs gravimetric water content, $\mathbf{f}$ suction vs degree of saturation (TD-11, 12, Table 1)

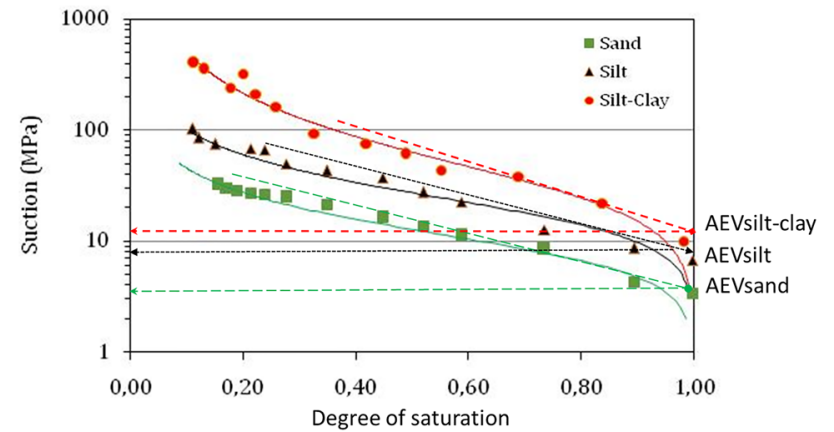

Fig. 19 Water retention curve for three types of mine tailings. AEV is the air entry value

saturated (Fig. 18c), although the drying process was very slow (Fig. 21d). The initial degree of saturation was not reached at any of the three depths during the 36 days of drying. Figure 18 shows that there were three evaporative stages associated with TDR 1 (the TDR located at $-6.5 \mathrm{~cm}$ in the vertical profile): initial, intermediate, and residual, and that each had a different slope.

In the initial stage, the evaporative front coincides with the tailings surface and the degree of saturation is constant $\left(S_{r}=1\right)$. At this stage, the capillary rise capacity can supply water to the evaporation front at a rate proportional to the demand imposed by atmospheric conditions. Evaporation does not depend at this stage on the characteristics of the tailings vertical profile, it is only controlled by the external weather conditions. Evaporation coincides with the capillary flow while the steam flow is zero. This stage is usually very brief, a few hours or days.

During the intermediate stage, the evaporation speed decreases: if the atmospheric conditions (relative humidity, solar radiation, and wind velocity) cause the evaporation to exceed the capillary rise capacity, then the suction in the soil will exceed the amount of air entering the tailings and the liquid phase will lose continuity. As a result, the evaporation front will move towards the interior of the vertical profile of tailings and steam flow will begin to be 
a
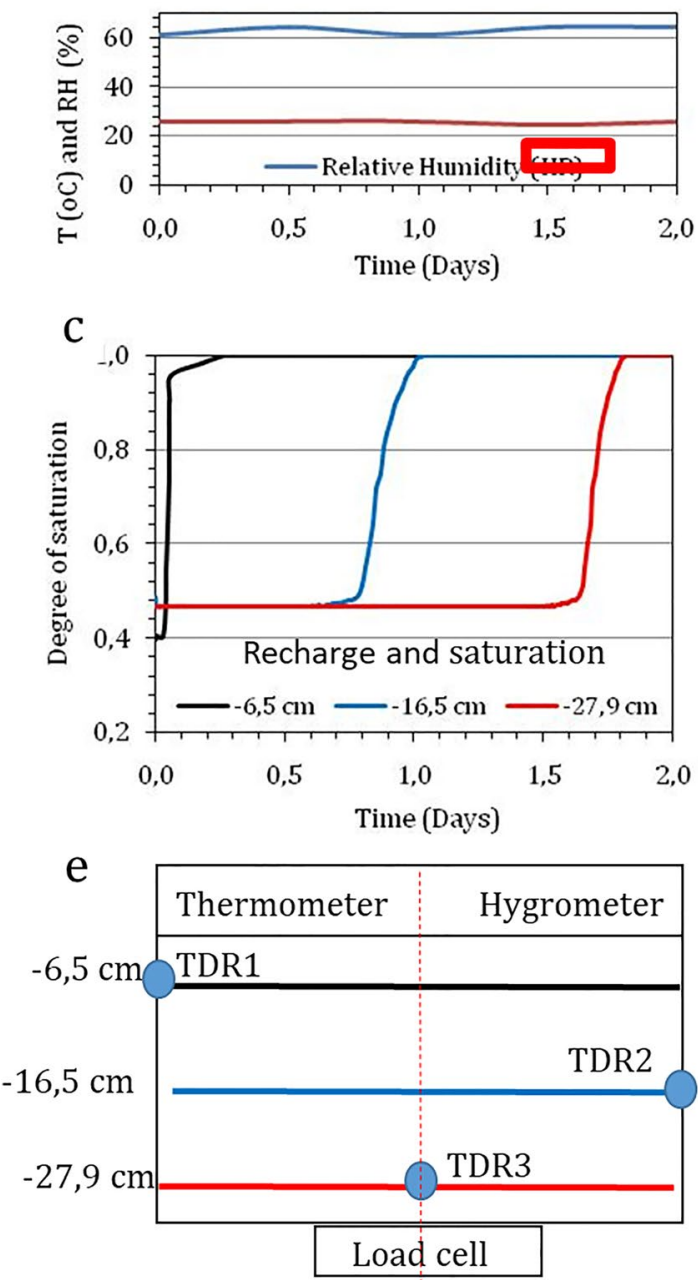

b

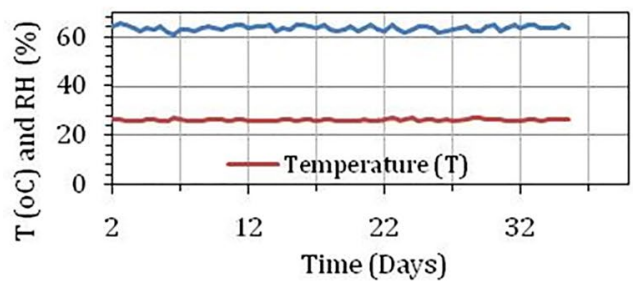

d

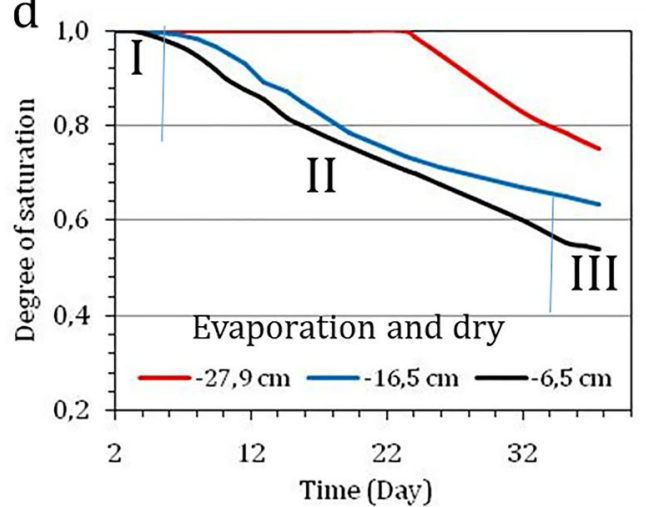

f

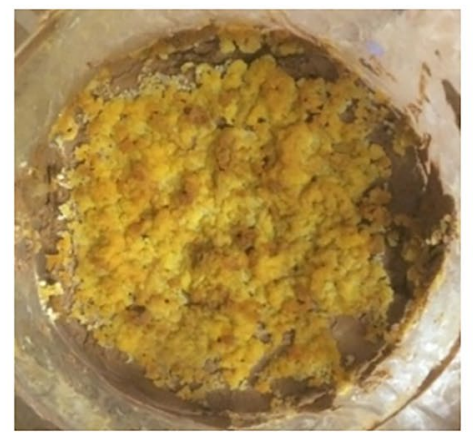

Fig. 20 Results of the experimental process of saturation and dry column of tailings a temperature and relative humidity in saturation process, b temperature and relative humidity in dry process, $\mathbf{c}$ evolution of the degree of saturation in vertical profile of the column, $\mathbf{d}$

generated. This stage usually lasts longer than the initial one but is still transitory.

During the residual or low evaporation speed stage, the atmospheric factors that favoured evaporation have less influence and therefore evaporation decreases. Occasionally there is equity between the terms of the psychometric law (Eq. 3) and the evaporation rate stabilizes again. At this stage, the evaporated flow is limited by the capillary flow from the water table to the evaporation front. Many times this parameter defines the position of the evaporation front, a few centimetres deep into the tailings profile.

The high suction value (2-300 MPa, Figs. 20, 21) and the formation of an efflorescent salt crust on the surface make evaporation difficult. This explains why TDs maintain such a high degree of saturation 50 years after their abandonment evolution of saturation in vertical profile during evaporation and dry processes, e scheme of the column with position sensors time domain reflectometer (TDR), $\mathbf{f}$ surface of the column with efflorescence on the surface of the column

(Fig. 13). The stationary regime of flow is reached very long after (see Zandarín et al. 2009). These results are consistent with Fisher (1928) and Pearce et al. (1949), who described the drying process of soils with models; again, three recognizable stages can be distinguished in their tests (Fig. 21d, TDR1 $-6.5 \mathrm{~cm}$ ).

The large variability of the hydraulic conductivity, added to the variability of other tailings features such as sedimentary architecture, dry density, and gravimetric water (Figs. 14, 18) causes TD basins to resemble highly anisotropic porous media, as previously shown (e.g. Kealy and Busch 1971; Oldecop et al. 2011; Rodríguez 2002, 2006b; Rodríguez and Oldecop 2006; Zandarín et al. 2008, 2009). 

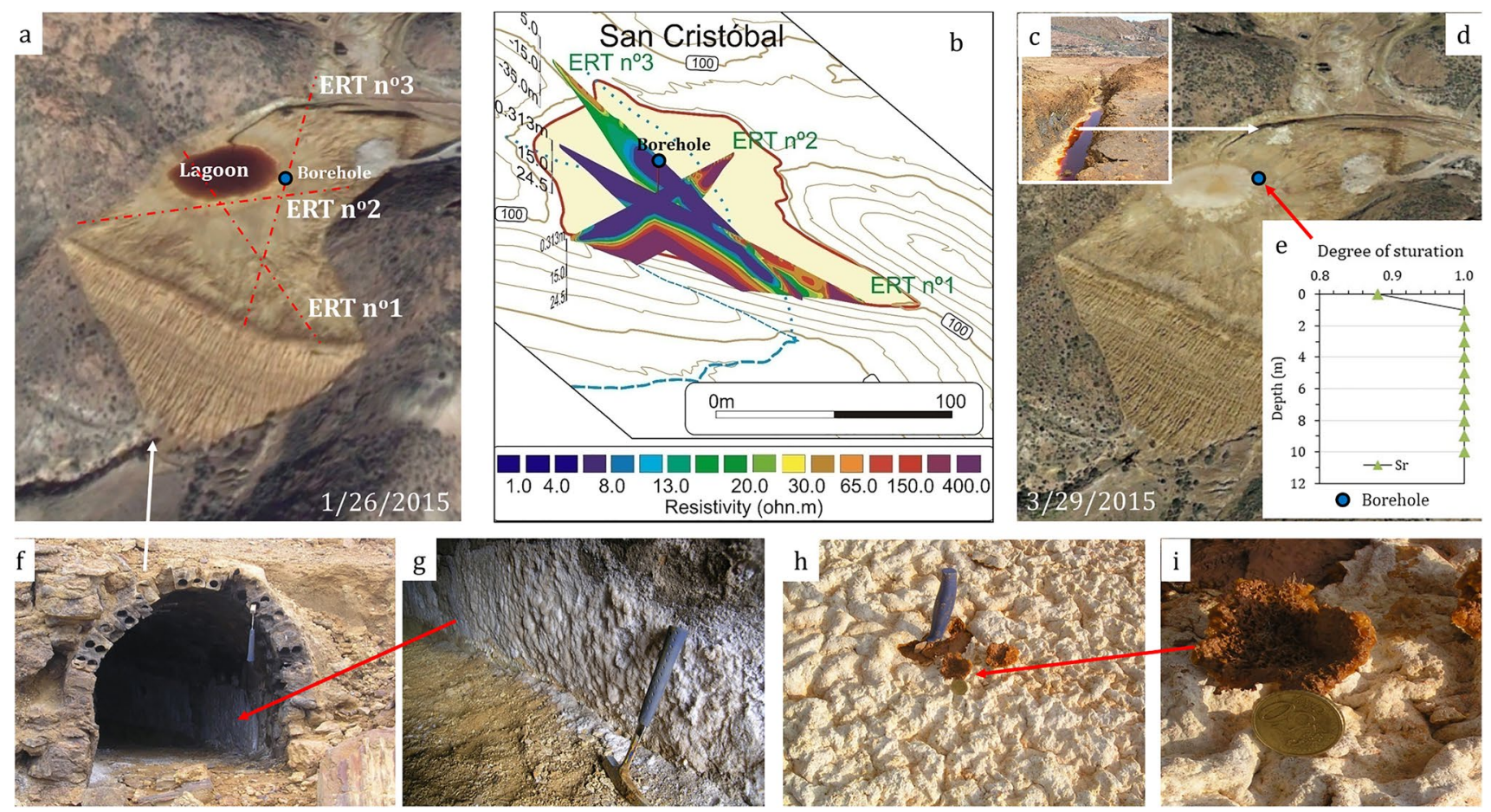

Fig. 21 a Localization of electrical resistivity profiles, b resistivity value, $\mathbf{c}$ water level and acid mine drainage in trench, $\mathbf{d}$ image with dried lagoon with efflorescence on surface e degree of saturation

\section{Geophysics}

Three resistivity profiles and boreholes were studied at one of the 14 TDs studied with electrical tomography (ET) is shown in Fig. 22a. Resistivity values between zero and eight correspond to fully saturated tailings (Fig. 22b, f). Electrical resistivity profiles and degree of saturation measured in samples taken from boreholes are consistent with a downward water flow front between the lagoon and the impoundment, with the saturation descending from the lagoon to the outer perimeter. This hydraulic gradient is controlled by the accumulation of rainwater and runoff in the lagoon (Figs. 3, 4, 5, 6, 22a, c). Similar resistivity patterns have been reported in other TDs (Acosta et al. 2011; Martínez-Pagán et al. 2009). Acid mine drainage can be observed in the trench (Fig. 22c). The evaporation processes cause superficial drying and precipitation of salts in the form of efflorescence (Fig. 22c-i). These crusts prevent deep evaporation due to their high suction, between 1 and $100 \mathrm{MPa}$ (Figs. 18, 19, 20). The tailings under the efflorescent crust are saturated, and a knife is inserted into the efflorescent crust structures (Fig. 22h). The efflorescences observed in the wall of the drainage gallery show the infiltration process and the precipitation due to the hydric deficit (Fig. 27i). measured in vertical profile in samples taken from boreholes, $\mathbf{f}$ view of a gallery that drains tailings, $\mathbf{g}$ efflorescence on the gallery wall, $\mathbf{h}$ tepees structure, $\mathbf{i}$ detail inside of tepees

\section{Geotechnical Stability Analysis: A Case Study}

According to the result of cartography carried out by IGME, 19 TDs show evidence of liquefaction (sand dikes and/or sand volcanoes) (IGME 2020). Of these, 17 have failed, 15 developed FF due to static liquefaction, and four had catastrophic consequences: Luciana 1962, Torre La Vega, Orconera 1964; Vizcaya; Brunita 1972, La Unión; Los Frailes-Aznalcóllar 1998, Sevilla. Earthquakes have never caused a TD failure in Spain (Table S-13).

Post-failure analyses can be used to understand the circumstances that caused a TD to fail and avoid similar failures elsewhere. However, post-failure analyses based on incomplete information on the characteristics of the deposit or their geotechnical behaviour can lead to misleading diagnoses. Post-failure analysis generally involves studying the tailings that have not failed and liquefied, since the actual conditions at the time of the TD failure are unknown (Alonso and Gens 2006; Fourie and Papageorgiou 2001; Luino and De Graff 2012; Macias et al. 2015).

The design, construction, filling, closure, and post-closure stages of the TDs may be analysed in terms of geotechnical stability by computing its geotechnical safety factor (SF). For this computation, the geotechnical features of the TDs must be modelled, and the quality of the geotechnical dataset 

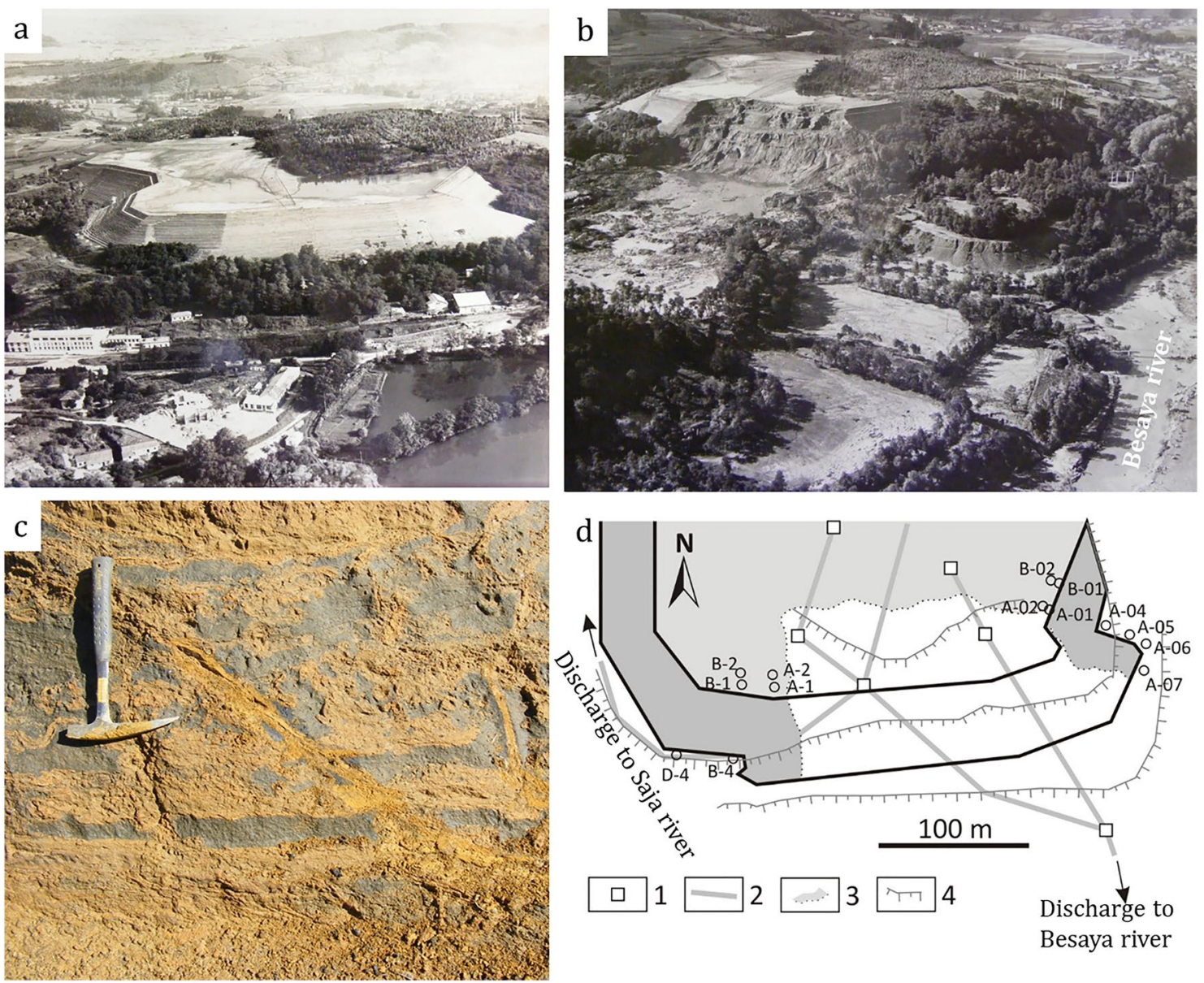

Fig. 22 a Tailings dam "La Luciana" before flow failure due to static liquefaction, $\mathbf{b}$ after the flow failure, $\mathbf{c}$ sand dykes due to static liquefaction, d location of the CPT boreholes and drainage system. 1 is tower of decantation. 2. Drainage system. 3. Slide surface. 4. Dump

used for the modelling is instrumental for such a model to resemble reality. Since the key in managing TDs is water balance (Rodríguez 2018), we will analyse the effect that water has on the geotechnical stability of the TD, with different boundary conditions. To illustrate that approach, we calculated the geotechnical stability of the La Luciana TD, which failed due to static liquefaction (Fig. 23). The failure of this TD was due to a chain of errors, the main one being the collapse of the drainage system. This was a rigid system built with concrete tubes (Berzal 1976; Fernández-Naranjo et al. 2015, 2019), which passed under the dam, constituting two points of weakness. This has been a common practice in TDs construction during the twentieth century.

Again, this is only a simplified model of the TD, based on data from the area that did not fail. A great deal of information is available on the geotechnical properties of the $\mathrm{La}$ Luciana TD, both in situ and in the laboratory (Berzal 1976; Crúz 2019; Fernández-Naranjo et al. 2015, 2019), there are high-quality images before and after the failure, and the causes of the failure are known. Despite the fact that this failure caused the greatest number of deaths in Spain, very little is known known about it (Table S-14). Furthermore, this TD had some very interesting characteristics. For example, evidence of static liquefaction can still be observed in the sand dikes that vertically cut the strata at the slip surface, 58 years after its abandonment or closing (Fig. 23d).

We used the Rock Science program to compute the SF because it considers five calculation methods, and is one of the most frequently used programs of numerical codes in the investigation of geotechnical stability of TDs (Garino 2018). The study considered the development of a circular or non-circular failure (Table S-14, Figs. 24, 25). Different boundary conditions were considered to constrain the model and five factors were taken into account: (1) the position of the decant lagoon, (2) the depth of the water table, (3) the pore pressure coefficient $\left(r_{u}\right)$, calculated using Eq. (7), (4) the pore or interstitial pressure, and (5) the change in the friction angle. 


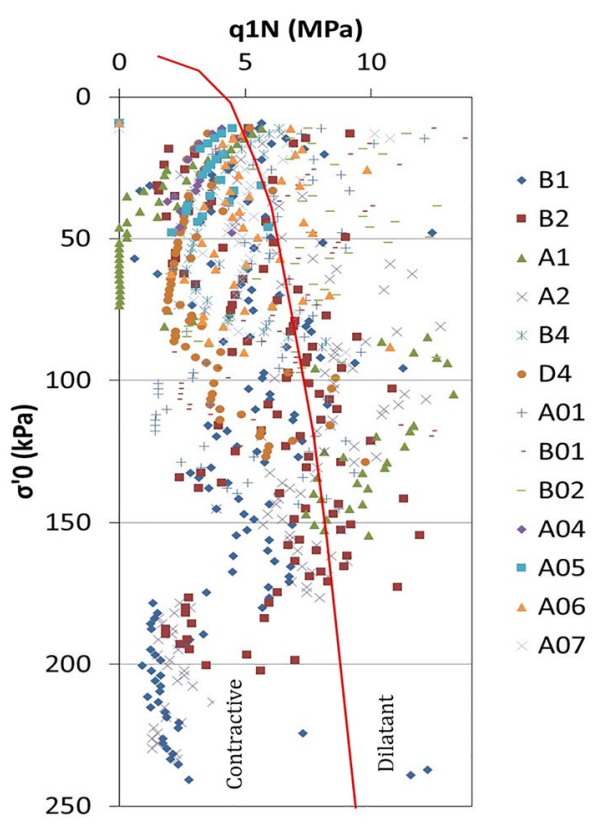

Fig. 23 Results of a CPT according to the criteria of Olson and Stark (2003) in fourteen boreholes in the tailings dam La Luciana. The legend indicates the boreholes location on the surface of TD Fig. 28d

$r_{u}=\frac{u}{\gamma * z}$

where $u$ is the pore water pressure, $\gamma$ is the unit weight of the soil, and $z$ is the depth below the ground. The aim of this geotechnical stability analysis was to determine the role of the different factors that triggered and controlled the TD failure, and to assess which was the most influential.

\section{Cone Penetration Tests}

Laboratory tests offer high-quality data, since the test conditions can all be controlled, but the integration of such data with more representative in situ tests is the most successful way to generate reliable geotechnical models. This is especially important when these models are used for stability analysis of complex structures such as TDs. In situ SPTs from the La Luciana TD are available (Fig. 21d). Figures 24 and 25 show the results of 14 cone penetration tests (CPTs; Fernández-Naranjo et al. 2015). The relative density (\%) and the contractive or dilatant behaviour of the porous material were analysed according to Bolton and Gui (1993) and Ishikara (1993). Note the presence of a contractive and dilatant sedimentary tailings layer in the vertical and horizontal profiles (Figs. 24, 25). The contractive materials also correlate with those with less relative density (Fig. 30). Analogous information on results of CPTs in TD in Spain can be found in previous studies (Crúz 2019; Emerman 2019; Fernández-Naranjo et al. 2015).

\section{The Effect of the Distance of the Decant Lagoon}

The effect of the distance of the decant lagoon on the SF were investigated within our model, using distances of 30, 20, 10, and $0 \mathrm{~m}$ (Table S-15, Fig. 26b). The trend seen in Fig. 31 shows that the closer the decant lagoon is to the dam (freeboard), the lower the SF. At $0 \mathrm{~m}$ from the slope, the SF obtained by the Fellenius method is 0.947 , an "unsafe" value, while the other methods show values just above the equilibrium value $(\mathrm{SF}>1)$.
Fig. 24 Assessment of the susceptibility of liquefaction through the CPT analysis on the left and relative density on the right. Note that the profile does not respond to a linear trace of the soundings

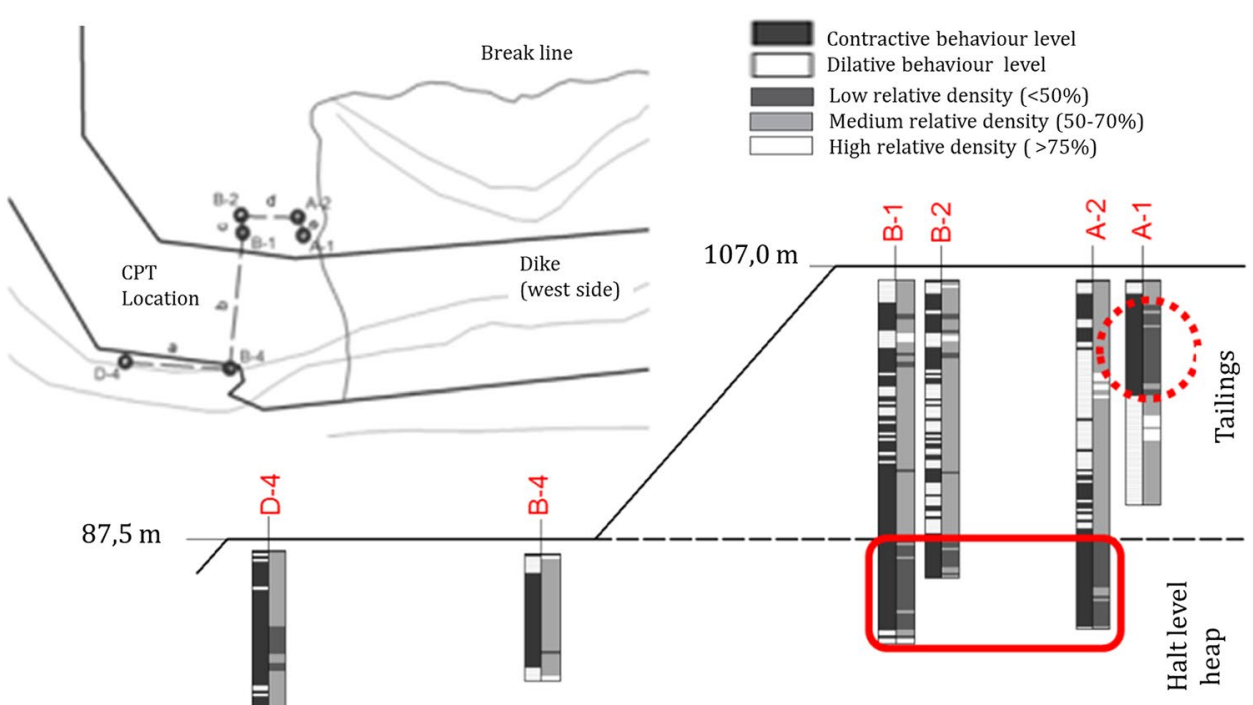

Horizontal scale: Vertical scale 1:2 
a

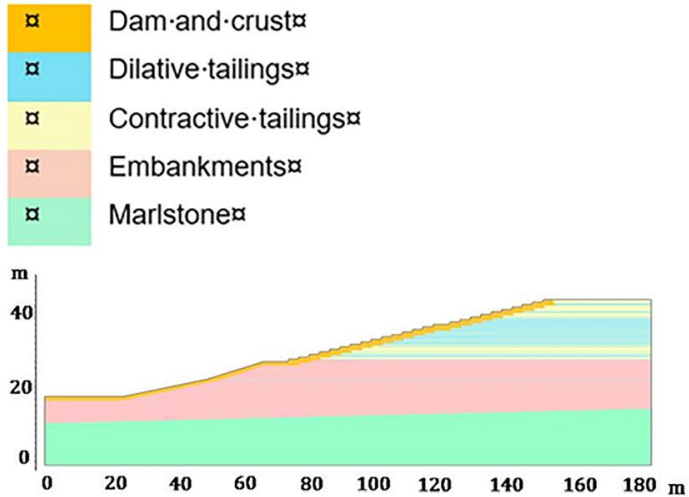

c

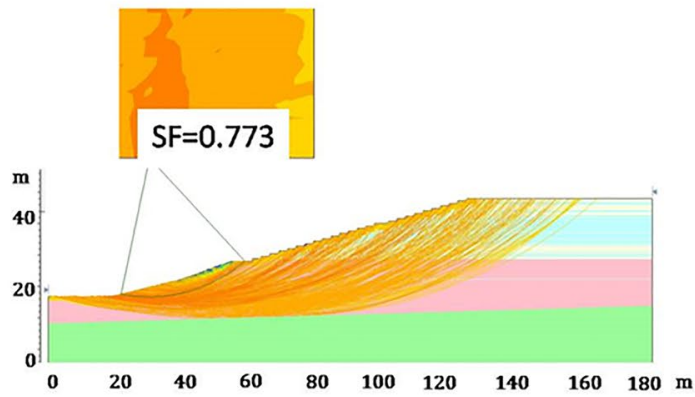

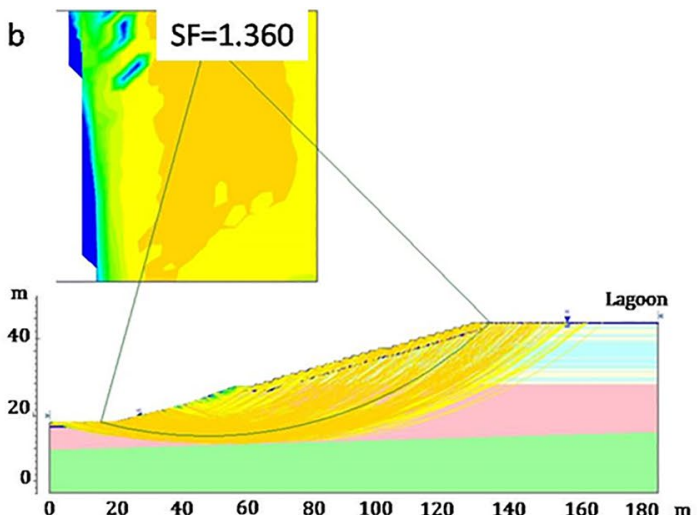

Safety factor

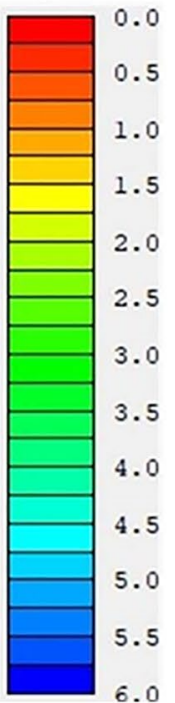

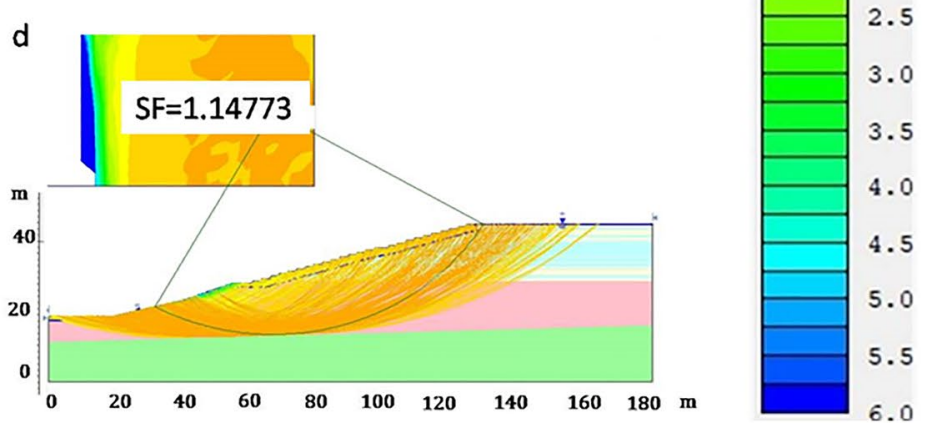

Fig. 25 a Geotechnical stratigraphy considered for the modelling, b the circular failure surface envelope for the Fellenius method with the decant lagoon at $0 \mathrm{~m}$ from the slope edge, $\mathbf{c}$ the circular failure sur- face envelope for the Bishop simplified method, at $r_{u}$ value of 0.6 , $\mathbf{d}$ the circular failure surface envelope for the Bishop method, with the water table height at surface

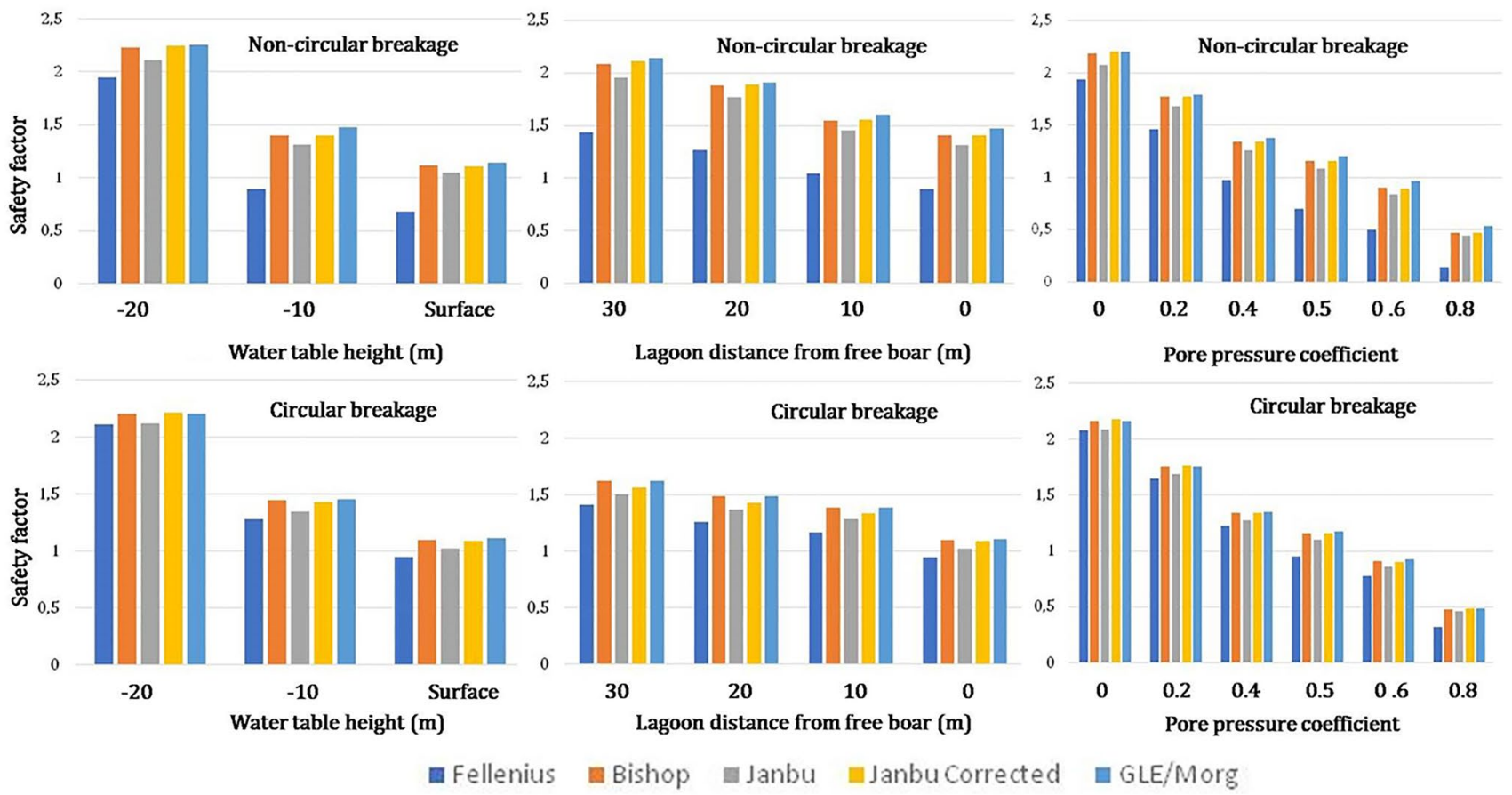

Fig. 26 Stability results of the TDs "La Luciana". a Fellenius method (1927), b simplified Bishop method (1955), c Janbu corrected method (1968), d GLE/Morgenstern-Price Method (1965) 


\section{The Effect of the Water Table Depth}

The water head had a negative effect on the dam's SF. When the water table was at a depth of $20 \mathrm{~m}$, the SF values were all $>2$, meaning the dam was safe. The Fellenius method exhibited unsatisfactory SF values when the water table was at the surface for circular $(\mathrm{SF}=0.947)$ and non-circular $(\mathrm{SF}=0.679)$ failures. The four other methods had values $>1$, but were deemed unsatisfactory, especially when the water table was at the surface (Table S-15, Fig. 26c).

\section{The Effect of the Pore-Pressure Coefficient $\left(r_{u}\right)$}

At a pressure coefficient value of 0.6 , all of the SF calculation methods present $\mathrm{SF}<1$. Figure $27 \mathrm{~d}$ shows the inverse relationship between the pore pressure coefficient and the SF. An increase in the pore pressure coefficient leads to a decrease in the SF. The Fellenius method exhibited unsatisfactory SF values when the pore pressure coefficient was 0.4 and 0.5 with a non-circular failure. Table S- 15 shows the effect that the pore-pressure coefficient (Eq. 7) within certain layers of the model has on the dam's SF.

\section{The Effect of the Pore-Pressure}

Pore pressure had no influence on the dam's geotechnical stability (Table S-15), at least for the case analysed. However, the sand dykes (water escape structures) found on the break surface indicate that static liquefaction took place (Fig. 23c).

\section{The Effect of the Internal Friction Angle}

Changing the internal friction angle of the tailings materials four-fold did not have a significant influence on geotechnical stability (Tables S-14, S-15), using the values obtained in our research (Fig. 15). Figure 27 and Table S-16 show the SF results for the La Luciana TD that failed, liquefied, and developed FF. The lower values of the SF obtained were again with the Fellenius method. Results show that the pore pressure coefficient had the greatest influence on the SF, regardless of the method used. Table S-16 shows the SF values recommended by different authors (Rodríguez 2018; WISE 2020).

\section{How to Prevent Flow Failures in Tailings Dams}

\section{The Concept and Characteristics of Drainage Systems and Tailing Management Have to Be Changed}

Unsaturated conditions reduce the possibility of liquefaction; good TD geotechnical stability can be achieved by reducing the degree of saturation below $80 \%$ in the impoundment and discharge zone or the beach. Initial drainage of the tailings is essential in new TDs; this also decreases the capillary height. Accordingly, a double drainage system (DDS), one for the unconsolidated materials of the foundation and another for the tailings, is required (Fig. 28). In addition, the drainage system must cut the entire vertical profile to favour the drainage and consolidation of the tailings, and has to be flexible enough to withstand the deformations of the tailings and the foundation without breaking. Drying of the tailings increase its density, uniaxial compressive strength, tensile strength, and decrease the pore pressure and the capillary height. Then, if the dam fails, the tailings will only travel a short distance (Oldecop and Rodari 2018; Rodríguez 2006).

At active TDs, adequate drainage control is necessary. In addition, the settling pond or lagoon should be kept as far as possible from the dam and the freeboard of the dam should exceed $1 \mathrm{~m}$. A good perimeter drainage system is necessary to avoid the entry of surface runoff water, as shown in Fig. 28.

Abandoned TDs require an adequate store-release cover and a drainage system that prevents water from entering the tailings dam basin. At closed TDs, the drainage system, deformations due to consolidation, accumulation of water on the surface, as well as the entry of water from surface runoff must all be controlled. Vehicular traffic on abandoned or restored tailings dams is inappropriate.

\section{Effect of Draining Tailings on Physical, Mechanical and Hydrogeological Properties}

We examined the consolidation of tailings under static loads in drained conditions with an oedometer. In all cases, such consolidation results in reduced volume (contractive), increased density, and reduced hydraulic permeability (Fig. 14). Draining the tailings can greatly increase density and decrease hydraulic permeability with a relatively small effective stress (Fig. 29). The remoulded samples (120 mm high and $100 \mathrm{~mm}$ in diameter) that we tested had different stratification thicknesses $(10,20$, and $40 \mathrm{~mm})$. The plots of shear strength vs. depth (Fig. 30) compare the beneficial effects of desiccation for a desert deposit featuring a dewatering tower rotation system with a deposit of continuously submerged tailings. If a linear relationship is assumed between shear strength and depth, the minimum strength envelope for the over-consolidated or desiccated tailings was more than an order of magnitude greater than for normally consolidated slimes in a continuously submerged deposit. The shear strength parameters of the tailings are controlled by the position of the lagoon and its capacity to dry and drain (Figs. 3, 4, 5, 6).

Geophysical techniques, such as electrical tomography (ET), should be used to determine saturated areas and zones, 
4Fig. 27 Conceptual model of hydro-mechanical operation of tailings dam a section, b plant. 1: rocks and consolidation materials in foundation, 2: unconsolidated materials, 3: started dam, 4: new dams, 5: sand, 6: silt, 7: silt-clay, 8: surface drainage, 9: geotextile, 10: lagoon or pond, 11: spigot of discharged tailings, 12: pumping pipe, 13: piezometer, 14: old tower, 15: drainage in foundations, 16: drainage in tailings, 17: surface drainage channel, 18: vertical drainage with gabion, 19: plant of filter and gabion image, 20: well of drainage, 21: plant drainage in tailings image, 22: plant drainage in foundation image, 23: plant tower image

and their relationship to groundwater flow and direction. Its cost is relatively low compared to other techniques, and the results are very useful. Furthermore, ET does not cause vibrations or place loads on the TD.

\section{Needed Changes}

The capillary rise and suction should be measured; new sensors make this easier (tensiometer, TDR, phychrometer, among others). The position of the lagoon can be controlled with cameras and satellite images at active, abandoned, and restored TDs. Conventional and advanced DInSAR can be used to monitor very fast mining subsidence with TerraSARX Data.

\section{Storage-Release Cover}

A storage-release cover and direct reforestation after closure or abandonment of the TDs have also been shown to reduce the degree of saturation. Figure $29 a-d$ show the different cover systems that use moisture store-and-release (Albright et al. 2010). The use of these covers depends on the physicochemical characteristics of the tailings. The experience in Spain shows that the vegetation does not grow on the TD surface if the $\mathrm{pH}$ is $<5.5$. In that case, it is necessary to seal the tailings surface with alternatives covers (Figs. 3c, 10a, $13 \mathrm{c}, 28 \mathrm{a}-\mathrm{e})$. When the $\mathrm{pH}$ is $>5.5$, the use of amendments and the addition of different types of soils allow vegetation to regenerate (Fig. 30). This increases the stability of the TDs, reduces their saturation, and allows a new land use. In areas with abundant rainfall, water cover closure is recommended (Bjelkevik 2005). It has been shown that the use of storage-release cover and vegetation in the closure of tailings dams reduces the degree of saturation in semiarid conditions (Oldecop et al. 2011).

The other solution is changing the nature of the tailings using relatively new technologies, such as thickened, paste, or filtered tailings, although it should be noted that these are not viable in certain climatic conditions (Lenhart 1950; Rodríguez 2018). Another technology that can be used to mitigate the risk of a FF is to generate a mixture of tailings and waste rock, which has the potential to avoid both acid formation and tailings liquefaction (Wickland et al. 2006).

\section{Discussion}

The design of TDs must have as its main objective to guarantee the physical stability of the dam, the drainage system, and the storage-release cover after closure. If the physical barrier does not fail, the risk of contamination and the rates of chemical contamination are greatly reduced. Clearly, however, active, abandoned, and restored TDs can and do fail, due to static or dynamic loads, and as a result of a chain of errors in design, construction, management, and closure. There is usually a final triggering mechanism, which is normally considered the cause of the failure (Figs. 1, 4) (Davies et al. 2002; ICOLD 2001; Oldecop and Rodríguez 2006; Rico et al. 2008; Rodríguez and García-Cortés 2006; Smith 1969, 1973).

Tailings dams are sedimentary basins, characterized by great spatial-temporal variation (Figs. 3, 4), with four zones in them: the dam, discharge zone, transition zone, and distal zone or lagoon (Fig. 17). There are stratification layers (Figs. 3, 6, 7) and sedimentary structures similar to natural sedimentary basins (Fig. S-3). Post-flotation wastes (mine tailings) consist of alternating sand, silt, and silty-sand layers, of variable thickness $(0.01-0.1 \mathrm{~m})$. The central pond of the dam basin is covered by a mantle of thinner sedimentary layers $(0.01-0.05 \mathrm{~m})$. The presence of sedimentary structures in TDs has been described by different authors (García 2004; Rodríguez et al. 2011; Smith 1969, 1973). The most notable structures are channels filled by silty deposits near the input zone, sediments eroded by a channel filled with cross-bedded deposits, planar and festoon-shaped crossbedded lamination in foresets of current ripples, desiccation cracks, paleo-channels, sand volcanoes, and sand dikes.

Tailings discharged into the basin undergoes horizontal and vertical segregation. Horizontal segregation develops where horizontal flow occurs, between the discharge and transition zones (Figs. 3-5, S-4). Vertical segregation takes place in the lagoon area. The latter zones are periodically flooded due to variations of the position, surface, and depth of the lagoon (Figs. 3, 4). Particle size decreases very slightly from the discharge zone towards the lagoon. These results have been observed elsewhere (Berzal 1976; Blight and Melentev 1994; Dorby and Álvarez 1967; Fourie and Papageorgiou 2001; Fourie et al. 2001; Okusa et al. 1980).

Field and laboratory tests show that the solids tailings sedimentary layers (porous media) are characterized by high anisotropy, due to their physical (Figs. 14, 15), mechanical (Figs. 14-16), and hydrogeological properties (Figs. 17-21). Our column experiments showed that tailings saturate much faster than they dry (Fig. 21), due to suction and capillary 
Fig. 28 Results over saturated sample of tailings. a Relationship between different confining effective stresses vs. dray density and $\mathbf{b}$ hydraulic conductivity vs. dry density

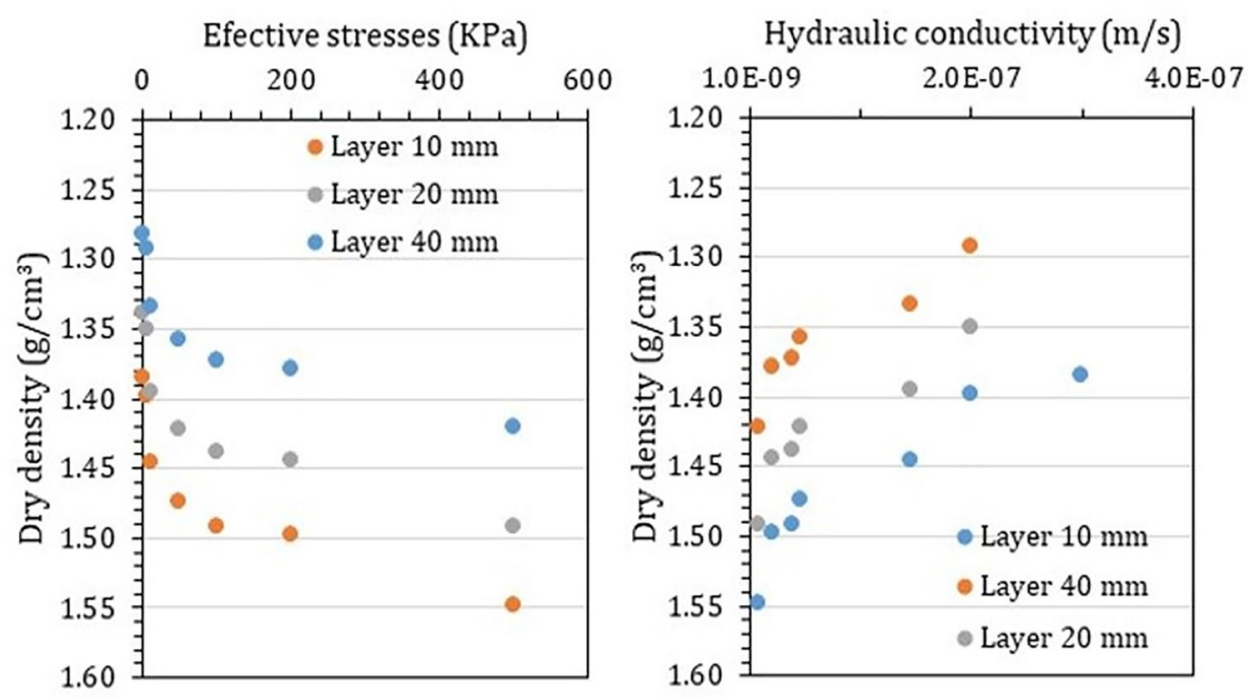

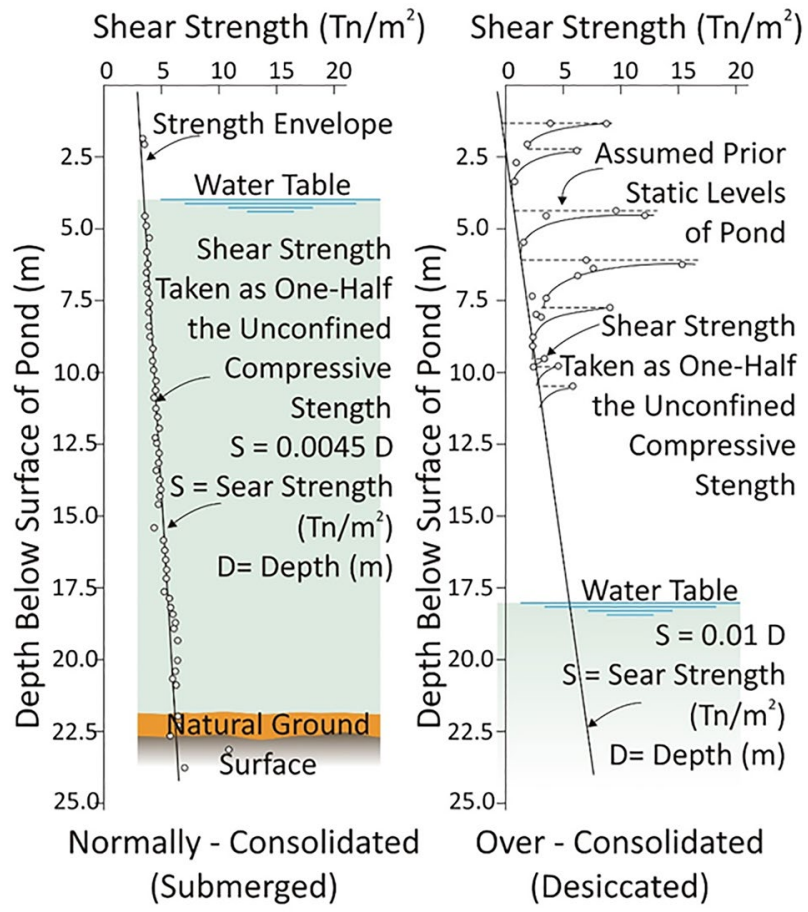

Fig. 29 Result a shear strength vs. depth in one tailings dam a submerged during deposition, $\mathbf{b}$ desiccated tailings due to interaction with atmosphere and drainage (modify from Smith 1969)

rise (Figs. 17, 18-21). This agrees with Dold and Fontbote (2001), who reported that tailings in the dam basin surface were unsaturated, but were saturated at depths below $2 \mathrm{~m}$ in the Andes' semi-arid climate. This behaviour was consistently observed in this study, regardless of the climatic condition (Figs. 3, 13, 20).

According to field observations and SPT results, TD basins consists of alternating layers of contractive and
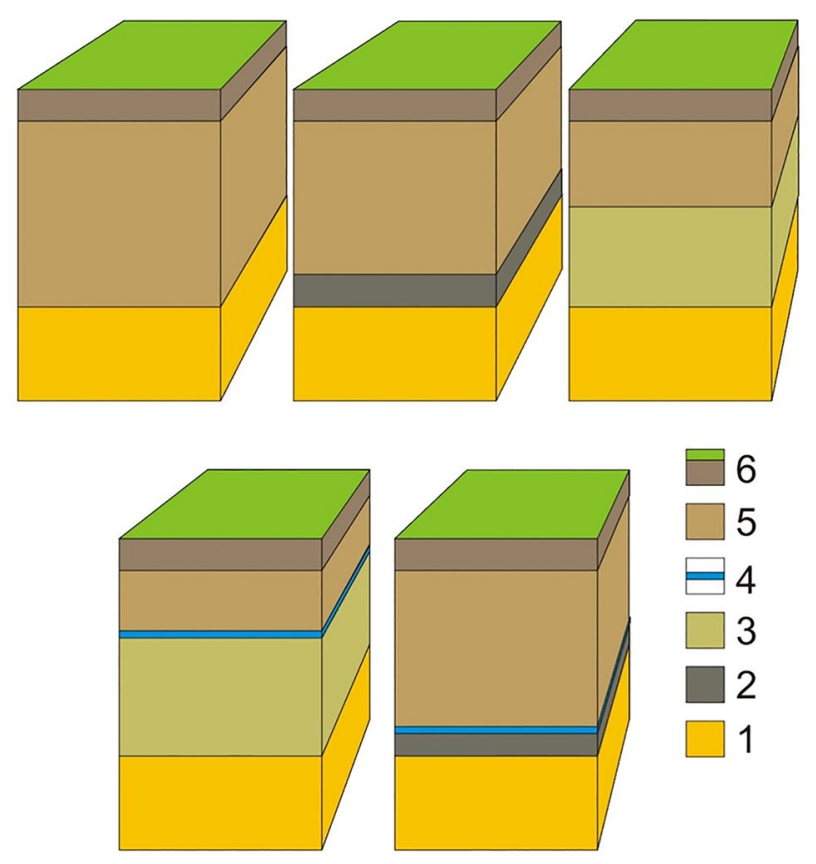

Fig. 30 Different types of storage-covers release used in the restoration and closure of TDs. 1: tailings, 2: original soil, 3: compacted clay, 4: drainage layer, 5: alternative materials, 6 : soil and vegetation

dilative materials (Figs. 14, 16, 24-26). They maintain a high degree of saturation because of their anisotropy, stratification (Figs. 4-9, 11, 27), and strong suction (Fig. 13). Despite this, our laboratory results show that tailings are always contractive, regardless of boundary conditions and test types, and collapse due to static and cyclic loading (Figs. 14, 16, 29).

The optimum water content that favours dam geotechnical stability ranges from 0.12 to 0.30 (Figs. 13, 14, 16, 29). The resistance parameters decrease when the saturation exceeds 
80\% (Okusa et al. 1980; Oldecop and Rodari 2018; Rodríguez 2002, 2006b, Rodríguez and Oldecop 2006). Controlling the degree of saturation in dams is becoming even more essential in the current context of climate change, which is producing a higher concentration of extreme precipitation events in the Mediterranean region.

In Spain, flow failures in TDs are associated with various triggering mechanisms (Fig. 1) mostly related to rain events and defective drainage systems (Table S-13). The grain-tograin fabric of mine tailings is responsible for their low plasticity and lack of cohesion, which makes them susceptible to liquefaction (Figs. 12, S-4).

The assessment of geotechnical safety factors showed that the pore-pressure coefficient $\left(r_{u}\right)$ controls tailings dam stability (Figs. 26, 27, Table S-15). When $r_{u}$ is $>0.5(\mathrm{Sr}=70 \%)$, the safety factor decreased abruptly. Thus, controlling the degree of saturation is the key to prevent TD flow failures. Such control can be achieved using a double drainage system (Fig. 28), one for the unconsolidated foundation materials and another for overlying tailings. Such systems must be designed to completely intersect the tailings deposit vertically. This design ensures appropriate drainage and consolidation of tailings, and that pore-fluid overpressures in any confined tailings strata are released.

Supervision and control of TD stability is necessary, either by the government or a company accredited for such purposes. New technologies, including satellite technology, drones, infrared cameras, and laser cameras, can support these needs and help ensure the stability of TDs. Also, the IGME has developed a methodology to assess the risk of TD failures (Alberruche et al. 2016) and is currently working on automating it.

\section{Conclusions}

Four temporal and spatial conditions that must exist simultaneously prior to a TD flow failure: (1) the tailings must experience contractive behaviour, (2) the tailings must be fully saturated $(\mathrm{Sr} \simeq 1),(3)$ the effective stress due to static or dynamic load must approach zero; and (4) the shear stress must exceed the tailings residual shear stress. Tailings dam flow failures due to liquefaction occur almost instantaneously and require undrained conditions.

Government and industry actions must focus on reducing the entry of water into the TD. The key condition is that the water balance must always be negative. A double drainage system (DDS) would facilitate water removal. The risk of dam failure reduces dramatically below $80 \%$ tailings saturation.

Supplementary Information The online version contains supplementary material available at https://doi.org/10.1007/s10230-021-00752-8.
Acknowledgements This research was supported by the Spanish Ministry of Industry, Commerce and Tourism (2013-2015) and from a management entrustment with the Spanish Ministry of Agriculture, Food and Environment (2012-2013). Thanks to the six anonymous reviewers and the editorial team of Rafael Fernández Rubio and Bob Kleinmann, for their valuable contributions and suggestions.

Open Access This article is licensed under a Creative Commons Attribution 4.0 International License, which permits use, sharing, adaptation, distribution and reproduction in any medium or format, as long as you give appropriate credit to the original author(s) and the source, provide a link to the Creative Commons licence, and indicate if changes were made. The images or other third party material in this article are included in the article's Creative Commons licence, unless indicated otherwise in a credit line to the material. If material is not included in the article's Creative Commons licence and your intended use is not permitted by statutory regulation or exceeds the permitted use, you will need to obtain permission directly from the copyright holder. To view a copy of this licence, visit http://creativecommons.org/licenses/by/4.0/.

\section{References}

Acosta JA, Martínez-Martínez S, Martínez-Pagan P, Zornoza R, Carmona DM, Faz A (2011) Estudio de estabilidad en depósitos de lodos del distrito minero de Mazarrón (SE España): Riesgos potenciales sobre la Rambla de Las Moreras. B Geol Minero 122(2):3-16 ([in Spanish])

Agurto-Detzel H, Bianchi M, Assumpção M, Schimmel M, Collaço B, Ciardelli C, Barbosa JR, Calhau J (2016) The tailings dam failure of 5 November 2015 in SE Brazil and its preceding seismic sequence. Geophys Res Lett 43(10):4929-4936. https://doi. org/10.1002/2016GL069257

Alberruche E, Arranz-González JC, Rodríguez R, Vadillo L, Rodríguez-Gómez V, Fernández-Naranjo FJ (2016) Simplified guide for closed/abandoned mining waste facilities risk assessment. Publisher: Ministerio de Agricultura y Pesca, Alimentación y Medio Ambiente. Madrid. www.researchgate.net/publicatio $\mathrm{n} / 312472577$

Albright WH, Benson CH, Waugh J, Down PhD (2010) Water balance covers for waste containment. Principles and practice. ASCE Press, Virgina

Alcolea A, Ibarra I, Caparrós A, Rodríguez R (2010) Study of the MS response by TG-MS in an acid mine drainage efflorescence. $\mathrm{J}$ Therm Anal Calorim 101(3):1161-1165. https://doi.org/10.1007/ s10973-009-0556-8

Alcolea A, Vázquez M, Caparrós A, Ibarra I, García C, Linares R, Rodríguez $\mathrm{R}$ (2012) Heavy metal removal of intermittent acid mine drainage with an open limestone channel. Miner Eng 26:86-98. https://doi.org/10.1016/j.mineng.2011.11.006

Alcolea A, Fernández-López C, Vázquez M, Caparrós A, Ibarra I, García C, Rodríguez R (2015) An assessment of the influence of sulfidic mine wastes on rainwater quality in a semiarid climate (SE Spain). Atmos Environ 107:85-94. https://doi.org/10.1016/j. atmosenv.2015.02.028

Alonso EE, Gens A (2006) Aznalcóllar dam failure. Part 1: Field observations and material properties. Géotechnique 56(3):165-183. https://doi.org/10.1680/geot.2006.56.3.165

ANCOLD (Australian National Committee on Large Dams) (2019) Guidelines on tailings dams - planning, design, construction, operation and closure-revision 1. www.ancold.org.au

ASTM (American Society of Testing Materials) (1992) Standard test method for penetration test and split barrel sampling of soils. D1586-84 
ASTM (2006a) Standard test method for determining transmissivity and storage coefficient of low-permeability rocks by in situ measurements using the constant head injection test. D4630-19

ASTM (2006b) Standard test method for direct shear test of soils under consolidated drained conditions. D3080/D3080M

ASTM (2006c) Standard test method for permeability of granular soils (constant head). D2434-19

ASTM (2006d) Standard test method for standard penetration test (SPT) and split-barrel sampling of soils. D1586/D1586M-18

ASTM (2006e) Standard test method for penetration test and split barrel sampling of soils. D 1586-84

ASTM (2009) Standard test methods for particle-size distribution (gradation) of soils using sieve analysis. D6913/D6913M-17

ASTM (2019) Standard test methods for one-dimensional consolidation properties of soils using incremental loading. D2435/ D2435M-11

Ayala-Carcedo FJ (2004) La rotura de la balsa de residuos mineros de Aznalcóllar (España) de 1998 y el desastre ecológico consecuente del Río Guadiamar: causas, efectos y lecciones. B Geol Minero 115:711-738 ([in Spanish])

Berzal JL (1976) Presas de residuos mineros. Revista de Obras Públicas 123:301-333 ([in Spanish])

Bjelkevik A (2005) Water cover closure design for tailings dams. State of the Art Report. Luleå Tekniska Univ. http://www.divaportal.org/

Blight G, Melentev E (1994) The master profile for hydraulic fill tailings beaches. Proc Inst Civ Eng Geotech Eng 107(1):27-40. https://doi.org/10.1680/igeng.1994.25718

Bolton MD, Gui MW (1993) The study of relative density and boundary effects of cone penetration tests in centrifuge. Univ of Cambridge, Dept of Engineering, Cambridge, UK, CUED/ DSOILS/TR256

Brown MC, Wigley TC, Ford DC (1969) Water budget studies in karst aquifers. J Hydrol 9(1):113-116. https://doi. org/10.1016/0022-1694(69)90018-3

CAN/BNQ (Standard Council of Canada) (2008) Soil-determination of the coefficient of permeability by Lefranc method. CAN/ BNQ 2501-135. www.scc.ca/

Cande SC, Kent DV (1995) Revised calibration of the geomagnetic polarity timescale for the Late Cretaceous and Cenozoic. J Geophys Res 100(B4):6093-6095

Caparrós AV (2017) Rheology of Pb-Zn post-flotation wastes in the Sierra de Cartagena-La Unión (SE Spain). PhD Diss, Polytechnic Univ of Cartagena, Spain. https://doi.org/10.31428 $/ 10317 / 7012$

Caruccio FT, Geidel G (1984) Induced alkaline recharge zones to mitigate acidic seeps. (No. CONF-841204-). Univ of South Carolina, Columbia, pp 27-36

Casagrande A (1950) Notes on the design of earth dams. Contributions to soil mechanics. Soc of Civil Engineers, Boston

Casagrande A (1975) Liquefaction and cyclic deformation of sands-a critical review. In: Proc, 5th Pan American conf in soil mechanics and foundation engineering, Buenos Aires, pp $81-83$

Casagrande L, MacIver BN (1970) Design and construction of tailings dams. In: Presentation 1st symp on stability in open pit mining, Vancouver

CDA (Canadian Dam Association) (2014) Technical Bulletin. Application of dam safety guidelines to mining dams. www.cda.ca

CDA (Canadian Dam Association) (2020) Dam Safety Guidelines. www.cda.ca/

Crippen K (2018) Static Liquefaction and Strength Loss in Tailings Dams. www.klohn.com/blog/static-liquefaction-strength-losstailings-dams

Cruz S (2019) Caracterización de las balsas mineras La Garma y El Gamoneo. Mijarojos, Cantabria. Escuela Politécnica de
Ingeniería de Minas y Energía. MSc Diss, Univ de Cantabria, Spain [in Spanish]

Davies MP, McRoberts EC, Martin TE (2002) Static liquefaction of tailings - fundamentals and case histories. Presented at the Tailings Dam. www.academia.edu/8146050

Dimos A (1991) Measurement of soil suction using transistor psychrometer. VIC ROADS, Internal report IR/91-3, Adelaide, USA

Dobry R, Alvarez L (1967) Seismic failures of Chilean tailings dam. J Soil Mech Found Div 93:237-260

Dold B (2014) Evolution of acid mine drainage formation in sulphidic mine tailings. Minerals 4(3):621-641. https://doi.org/10.3390/ $\min 4030621$

Dold B, Fontboté L (2001) Element cycling and secondary mineralogy in porphyry copper tailings as a function of climate, primary mineralogy, and mineral processing. J Geochem Explor 74(1-3):3-55. https://doi.org/10.1016/S0375-6742(01)00174-1

Dold B, Fontboté L (2002) A mineralogical and geochemical study of element mobility in sulfide mine tailings of $\mathrm{Fe}$ Oxide $\mathrm{Cu}-$ $\mathrm{Au}$ deposits from the Punta del Cobre belt, northern Chile. Chem Geol 189(3-4):135-163. https://doi.org/10.1016/S0009 -2541(02)00044-X

Emerman SH (2019) Emerman SH (2019) Risk analysis of the tailings dams at the Rio Tinto Mine, Andalusia, Spain. Report prepared at the request of London Mining Network, Malach Consulting. www.londonminingnetwork.org/wp-content/uploads/2019/11/ RioTinto_Report_190930.pdf

Fernández Naranjo FJ, Rodriguez-Gomez V, Rodríguez-Pacheco R, Alberruche E, Arranz-González JC, Sarro R, Mateos R, Herrera G, Vadillo L (2019) Analysis of tailings dam failure based on historical documents: the case study of "La Luciana", Spain. In: Conf: JTC1 workshop on advances in landslide understanding, Barcelona

Fernández-Naranjo FJ, Rodríguez-Gómez V, Rodríguez R, Alberruchedel Campo ME, Arranz-González JC, Vadillo L (2015) Liquefaction susceptibility assessment and study of "La Luciana" tailings dam fault (Spain, 1960) based on historical documents. Dyna 82(189):189-198

Firmana Y, Schanz T (2009) Osmotic suction of highly plastic clays. Acta Geotech 4(3):177-191. https://doi.org/10.1007/s1144 0-009-0097-0

Fisher RA (1928) Further note on the capillary forces in an ideal soil. J Agric Sci 18(3):406-410

Fourie AB, Papageorgiou G (2001) Defining an appropriate steady state line for Merriespruit gold tailings. Can Geotech J 38(4):695-706. https://doi.org/10.1139/t00-111

Fourie AB, Blight GE, Papageorgiou G (2001) Static liquefaction as a possible explanation for the Merriespruit tailings dam failure. Can Geotech J 38(4):707-719. https://doi.org/10.1139/t02-079

Gammons CH, Mulholland TP, Frandsen AK (2000) A comparison of filtered vs. unfiltered metal concentrations in treatment wetlands. Mine Water Environ 19(2):111-123. https://doi.org/10.1007/ BF02687259

García C (2004) Impacto y riesgo ambiental de los residuos minerometalúrgicos de la Sierra de Cartagena-La Unión (MurciaEspaña). PhD Diss, Univ Politécnica de Cartagena, Spain [in Spanish]

Garino L (2018) Estudio del comportamiento mecánico de residuos mineros ubicados en zonas áridas, PhD Diss, Univ Nacional de San Juan, República Argentina [in Spanish]

Hazen A (1918) A study of the slip in the Calaveras Dam. Eng News Rec 81(26):1158-1164

ICOLD (International Commission on Large Dams) (1982) Manual on tailings dams and dumps. Bull 45. Río de Janeiro

ICOLD (2001) Tailings dam-risk of dangerous occurrences. Lessons learnt from practical experiences. Bull 121. Commission Internationale des Grands Barrages, Paris 
IGME (Instituto Geológico y Minero de España) (2010) Mapa geológico de España. Escala 1:50000 (in Spanish). http://info. igme.es/cartografiadigital/geologica/Magna50.aspx

IGME (2020) http://igme.maps.arcgis.com/home/webmap/viewer.html. Accessed 12 Jan 2020

IGN (Instituto Geográfico Nacional de España) (2020). www.ign.es. Accessed 12 Jan 2020

Ishihara K, Troncoso J, Kawase Y, Takahashi Y (1980) Cyclic strength characteristics of tailings materials. Soils Found 20(4):127-142

Ishikara K (1993) Liquefaction and flow failure during earthquakes. Geotechnique 43(3):351-415

ISO (International Organization for Standardization) (2009) Particle size analysis. Laser diffraction methods, ISO 13320:2009. www.iso.org/

Jennings JN (1971) Karst-an introduction to systematic geomorphology, vol 7. The MIT Press, Cambridge

Johnson AI (1967) Specific yield-compilation of specific yield for various material. U.S. Govt Printing Office, no. 1662

Kealy CD, Busch RA (1971) Determining seepage characteristics of mill-tailings dams by the finite-element method. U.S. Bureau of Mines RI 7477, Washington DC

Knappett J, Craig RF (2012) Craig's soil mechanics. CRC Press, New York. www.academia.edu/36825611

Kokusho T (1991) Formation of water film in liquefied sand and its effect on lateral spread. J Geotech Geoenv Eng Div 125(10):817-826. https://doi.org/10.1061/ (ASCE)1090-0241(1999)125:10(817)

Kokusho T (2003) Current state of research on flow failure considering void redistribution in liquefied deposits. Soil Dyn Earthq Eng 23(7):585-603. https://doi.org/10.1016/S0267 $-7261(03) 00067-8$

Kokusho T, Kojima T (2002) Mechanism for postliquefaction water film generation in layered sand. J Geotech Geoenviron Eng Div 128(2):129-137. https://doi.org/10.1061/ (ASCE) 1090-0241(2002)128:2(129)

Ladd CC (1986) Stability evaluation during staged construction. The 22nd Karl Terzaghi Lecture. Boston J Geotech Eng 117:537-615

Lenhart W (1950) Control of tailings from washing plants. Rock Prod 53(7):72-80

Lloret A, Rodríguez R, Ríos J (1999) Ensayos sobre muestras procedentes de Aznalcóllar. Technical Report, Dept de Ingeniería del Terreno, Cartográfica y Geofísica, Univ Politécnica de Cataluña, Barcelona (in Spanish)

Luino F, De Graff JV (2012) The Stava mudflow of 19 July 1985 (Northern Italy): a disaster that effective regulation might have prevented. Nat Hazards Earth Syst Sci 12:1029-1044. https://doi. org/10.5194/nhess-12-1029-2012

Macho A, Vadillo L, Rodríguez L, Fernández-Naranjo FJ, ArranzGonzález JC, Alberruche ME, Rodríguez-Gomez V (2014) Metodología para la realización de un inventario de instalaciones de residuos mineros cerradas o abandonadas. Ministerio de Agricultura, Alimentación y Medio Ambiente (in Spanish). www. researchgate.net/publication/277006709

Macías JL, Corona-Chávez P, Sanchéz-Núñez JM, Martínez-Medina M, Garduño-Monroy VH, Capra L, García-Tenori F, CisnerosMáximo G (2015) The 27 May 1937 catastrophic flow failure of gold tailings at Tlalpujahua, Michoacán, Mexico. Nat Hazards Earth Syst Sci 15:1069-1085. https://doi.org/10.5194/nhess $-15-1069$

Martin T, McRoberts EC (1999) Some considerations in the stability analysis of upstream tailings dams. In: Proc 6th international conf on tailings and mine waste. www.researchgate.net/publi cation/255509946
Martin TE, McRoberts EC, Davies MP (2002) A tale of four upstream tailings dams. In: Proc, 9th international conf on tailings and mine wastes (10.1.1.532.7955).

Martínez-Pagán P, Faz A, Aracil E, Arocena JM (2009) Resistivity imaging revealed the spatial properties of mine tailing ponds in the Sierra Minera of Southeast Spain. J Environ Eng Geophys 14(2):63-76. https://doi.org/10.2113/JEEG14.2.63

Martínez-Pagán P, Faz A, Acosta JA, Carmona DM, Martínez-Martínez S (2011) A multidisciplinary study for mining landscape reclamation: a study case on two tailings ponds in the region of Murcia (SE Spain). Phys Chem Earth 36:1331-1344

Moller P, Fall A, Chikkadi V, Derks D, Bonn D (2009) An attempt to categorize yield stress fluid behaviour. Philosop Trans R Soc A 367:5139-5155. https://doi.org/10.1098/rsta.2009.0194

Morgenstern R, Vick SG, Viotti CB, Watts BD (2016) Fundão tailings dam review panel. Report on the immediate causes of the failure of the Fundão Dam. http://fundaoinvestigation.com/wp-content/ uploads/general/PR/en/Final

Newland L (2014) Tailings impoundment failure rates: a new look at the WISE \& ICOLD data. www.lindsaynewlandbowker.wordp ress.com/2014/10/17/tailings-impoundment-failure-rates-a-newlook-at-the-wise-icold-data/

Nguyen QD, Boger DV (1998) Application of rheology to solving tailings disposal problems. Int J Miner Process 54:217-233. https:// doi.org/10.1016/S0301-7516(98)00011-8

Okusa S, Anma S, Maikuma H (1980) Slope failures and tailings dam damage in the 1988 Izu-Ohshima-Kinkai earthquake. Eng Geol 16:195-224

Oldecop L, Rodari G (2018) Unsaturated soil mechanics in mining. In: 2nd Pan-American conf on unsaturated soils. https://doi. org/10.1061/9780784481677.014

Oldecop L, Rodríguez R (2006) Estabilidad y seguridad de depósitos de residuos mineros. In: Rodríguez R, García-Cortés A (eds) Los residuos minero metalúrgicos en el medio ambiente. IGME, Madrid, pp 197-243. www.researchgate.net/publication/26374 7187 (in Spanish)

Oldecop LA, Zandarín MT, Rodríguez R (2008) Stability of a tailing dam considering the hydro-mechanical behaviour of tailings and climate factors. In: Unsaturated soil: advances in geo-engineering, Taylor \& Francis Group, pp 925-931. www.researchgate.net/ publication/263739172

Oldecop LA, Garino L, Muñoz JJ, Rodriguez R, García C (2011) Unsaturated behaviour of mine tailings in low precipitation areas. In: Unsaturated soils, Taylor \& Francis Group, London, pp 1425-1430. https://doi.org/10.13140/RG.2.1.4660.7527

Olson SM, Stark TD (2003) Yield strength ratio and liquefaction analysis of slopes and embankments. J Geotech Geoenviron Eng 129(8):727-737. https://doi.org/10.1061/ (ASCE)1090-0241(2003)129:8(727)

Pearce JF, Olivier TR, Newitt DM (1949) The mechanism of the drying of soils. Part I: the forces giving rise to movement of water on granular beds during drying. Trans Inst Chem Eng 27:1-8

Rico R, Benito G, Salgueiro AR, Díez-Herrero H, Pereira HG (2008) Reported tailings dam failures: a review of the European incidents in the worldwide context. J Hazard Mat 152:846-852. https ://doi.org/10.1016/j.jhazmat.2007.07.050

Robertson PK (2010) Evaluation of flow liquefaction and liquefied strength using the cone penetration test. J Geotech Geoenv Eng 136:842-853. https://doi.org/10.1061/(ASCE)GT.19435606.0000286

Rodríguez R, Lloret A, Ledesma A, Candela L (1998) Characterization of Mine Tailings in the Cuba Nickel Industry In Environmental geotechnic. Publisher A.A Balkema

Rodríguez R, Oldecop L (2006) Propiedades físicas, mecánicas e hidrogeológicas de los residuos minero-metalúrgicos sólidos. In: Rodríguez R, García-Cortés A (eds) Los residuos minero 
metalúrgicos en el medio ambiente, (IGME). https://urldefense .proofpoint.com/v2/url?u=https-3A__www.researchgate.net_ publication_263747187\&d=DwIFAw\&c $=$ vh6FgFnduejNhPP D0fl_yRaSfZy8CWbWnIf4XJhSqx 8\&r=JxLWRfjFp6vfB3I FaoebJyW9FDaWphq90ThmiabxzFjy41HQKY8zLSK4Xr3p cgMP\&m=QMv9C5nsmOFY47pZ3e8Pd08hFjZoDu7PN2y SHU6kxoE\&s=NLsluXN5EYjZiP88DV__T7aIZz8FWZtkBnO onX5VWFg\&e $=$

Robertson PK, de Melo L, Wiliams DJ, Wilson GW (2019) Report of the expert panel on the technical cause of the failure of Feijão Dam I. 2019. http://www.b1technicalinvestigation.com

Roche C, Thygesen K, Baker E (2017) Rapid response assessment. Mine tailings storage: safety is no accident. A UNEP Rapid Response Assessment. United Nations Environment Programme and GRID-Arendal, Nairobi and Arendal. http://www.grida.no/ publications $/ 383$

Rodríguez R (2002) Estudio experimental de flujo y transporte de cromo, níquel y manganeso en residuos de la zona minera de Moa (Cuba): influencia del comportamiento hidromecánico. Thesis, Polytechnic Univ Cataluña. www.tdx.cat/handle/10803 $/ 6223$ (in Spanish)

Rodríguez R (2006) Hydrogeotechnical characterization of a metallurgical waste. Can Geotecl J 43:1042-1060. https://doi. org/10.1139/t06-061

Rodríguez R (2018) Static liquefaction in tailings dam and flow failure. Presentation, Seminario riesgos geotécnicos. www.researchga te.net/publication/331277260

Rodríguez R, García-Cortés A (2006) Los residuos minero metalúrgicos en el medio ambiente Instituto Geológico y Minero de España (in Spanish)

Rodríguez R, Gómez de las Heras J (2006) Los residuos de la industria extractiva en España. Distribución geográfica y problemática ambiental asociada. In: Rodriguez R, García-Cortez A (eds) In Los residuos minero-metalúrgicos en el medio ambiente. IGME, Madrid (in Spanish)

Rodríguez R, Candela L, Lloret A (2004) Experimental system for studying the hydromechanicalbehaviour of porous media. Vadose Zone J 4:345-353

Rodríguez R, Candela L, Lloret A (2006) Apparatus for evaluation of haydomechanicalbehaviour of porous media subjected to environmental changes. Geotech Test J 29:9-20

Rodríguez R, Candela L, Lloret A, Pérez T, Cortés F (2006b) Dispositivo para la caracterización de medios porosos sujetos a diferentes condiciones ambientales y de contorno. Patente. Oficina de española de patentes y marcas, número de publicación 2241477. www.researchgate.net/publication/263714543 (in Spanish)

Rodríguez R, Sánchez M, Ledesma A, Lloret A (2007) Experimental and numerical analysis of desiccation of a mining waste. Can Geotech J 44:644-658. https://doi.org/10.1139/t07-016

Rodríguez R, García-García C, Zarroca M, Roqué C, Linares R, Oldecop L (2011) Características geológicas y geotécnicas de los lodos de flotación de la Sierra Minera de Cartagena-La Unión (SE España). B Geol Minero 122:127-144 ((in Spanish))

Smith ES (1969) Tailings disposal and liquefaction. T Soc Min Eng (AIME) 244:179-187

Smith ES (1973) Tailings disposal. Failures and lessons. In: Alpin L, Argall Jr G (eds) Proc. tailing disposal today, 1st international tailing symp, Miller Freeman Publications, pp 356-376

Terzaghi K, Peck GM (1996) Soil mechanics in engineering practice. Wiley, New York

Van Zyl D, Robertson AM (1980) Subsurface drainage of tailings impoundments: some design, construction and management considerations. In: Presentation symp on uranium mill tailings management. http://pdfs.semanticscholar.org/8549

Verdugo R (2012) Comparing liquefaction phenomena observed during the 2010 Maule, Chile earthquake and 2011 great east Japan earthquake. In: Proc. international symp on engineering lessons learned from the 2011 Great East Japan Earthquake. www.seman ticscholar.org/paper

Vick S (1992) Stability evaluation during staged construction-discussion. ASCE J Geotech Eng 118:1282-1289. http://worldcat.org/ issn/07339410

Vitton S, Sadler L (1997) Particle-size analysis of soils using laser light scattering and $\mathrm{x}$-ray absorption technology. Geotech Test $\mathrm{J}$ 20(1):63-73. https://doi.org/10.1520/GTJ11421J

Whitman RV (1987) Liquefaction-the state of knowledge. B N Z Nat Soc Earthq Eng 20(3):145-158. http://www.nzsee.org.nz/db/ Bulletin/Archive/20(3)0145

Wickland BE, Ward G, Wijewickreme D, Klein B (2006) Design and evaluation of mixtures of mine waste rock and tailings. Can Geotech J 43(9):928-945. https://doi.org/10.1139/t06-058

WISE (World Information Service on Energy) (2020) www.wise-urani um.org. Accessed 18 Jan 2020

WMTF (World Mine Tailings Failures) (2020) http://worldminetailin gsfailures.org. Accessed 12 Jan 2020

Youd TL (1972) Compaction of sands by repeated shear straining. J Soil Mech Found Div 98(7):709-725

Yu D, Tang L, Chen C (2019) Three-dimensional numerical simulation of mud flow from a tailings dam failure across complex terrain. Nat Hazards Earth Syst Sci 20(3):727-741. https://doi. org/10.5194/nhess-2019-298

Zandarín MT, Oldecop L, Rodríguez R (2008) Satability of tailings dam considering the hydro-mechanical behaviour of tailings and climate factors. I Unsaturated Soils: Advances in Geo-EngineeringPublisher: Taylor \& Francis Group, London

Zandarín MT, Oldecop LA, Rodríguez R, Zabala F (2009) The role of capillary water in the stability of tailing dams. Eng Geol 105:108-118. https://doi.org/10.1016/j.enggeo.2008.12.003

Zarroca M, Linares R, Velásquez-López PC, Roque C, Rodríguez R (2015) Application of electrical resistivity imaging (ERI) to a tailings dam project for artisanal and small-scale gold mining in Zaruma-Portovelo, Ecuador. J Appl Geophys 113:103-113 